\title{
CITY OF MCFARLAND LAND USE ELEMENT UPDATE
}

\author{
A Project \\ presented to \\ The Faculty of California Polytechnic State University, \\ San Luis Obispo
}

\section{In Partial Fulfillment \\ of the Requirements for the Degree \\ Master of City and Regional Planning}

\author{
by \\ Jeffrey James Ballantine \\ June 2011
}


(C) 2011

Jeffrey James Ballantine

ALL RIGHTS RESERVED 
COMMITTEE MEMBERSHIP

TITLE:

CITY OF MCFARLAND LAND USE ELEMENT UPDATE

AUTHOR: Jeffrey James Ballantine

DATE SUBMITTED: June, 2011

COMMITTEE CHAIR Michael Boswell, Ph.D, AICP, Professor

COMMITTEE MEMBER: Kelly Main, Ph.D, Assistant Professor

COMMITTEE MEMBER: Paul Wack, AICP, Professor 


\section{ABSTRACT \\ City of McFarland Land Use Element Update \\ Jeffrey James Ballantine}

The City of McFarland, CA is in the process of updating its General Plan and identified updating the land use element as the first step in this process. This land use element consists of a land use diagram, land use standards, and goals, policies, and programs. These components of the document are based upon community feedback as well as upon analysis of case studies and state and regional guidelines. The final plan accommodates for increased residential densities, a mixture of adjacent land uses, a greenbelt, and large areas of land adjacent to Highway 99 for commercial and industrial use.

Keywords: land use planning, General Plan, land use element. 


\section{Table of Contents}

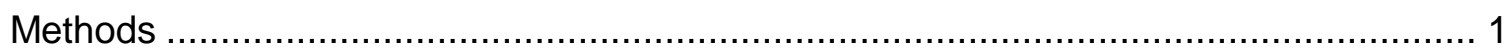

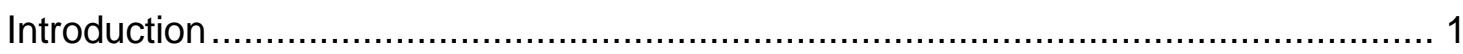

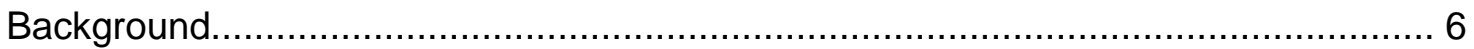

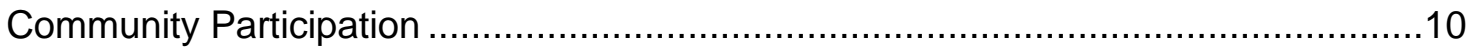

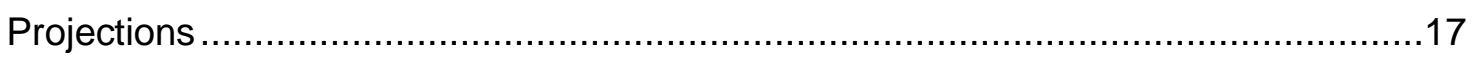

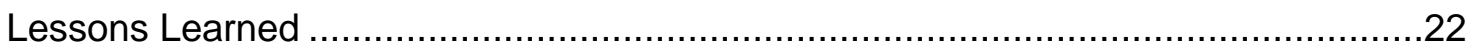

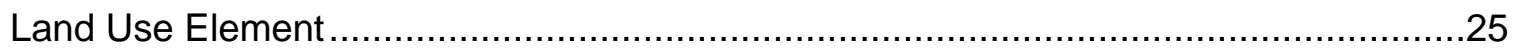

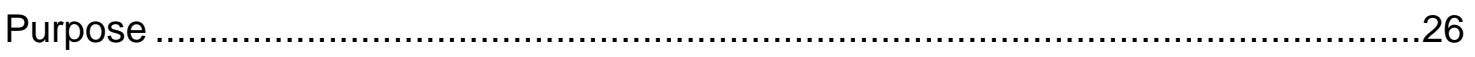

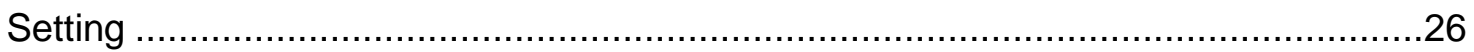

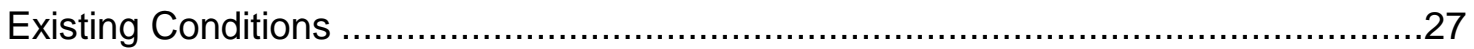

Previous Residential Development ………………..........................................

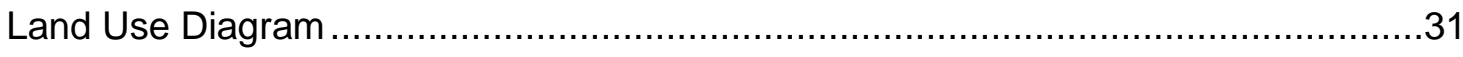

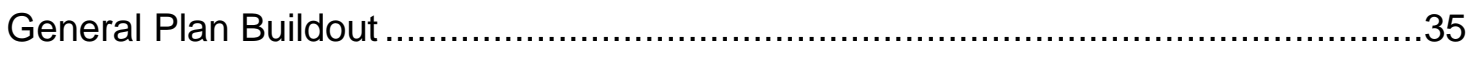

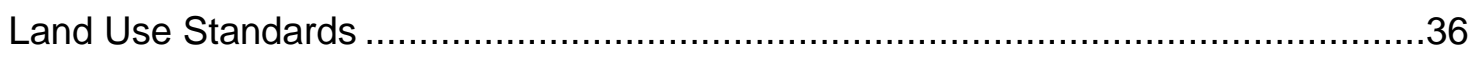

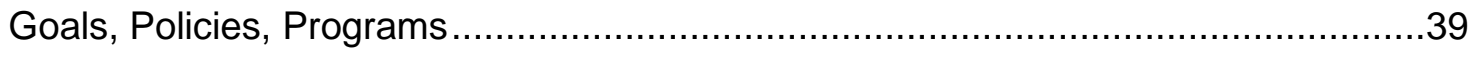

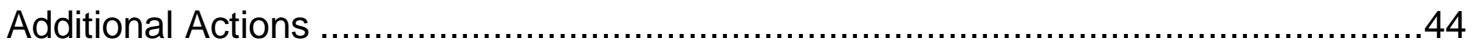

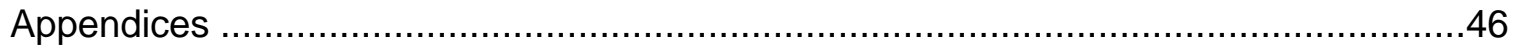

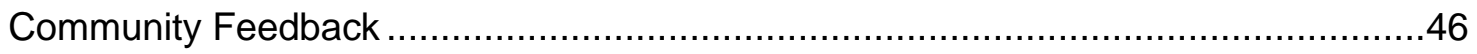

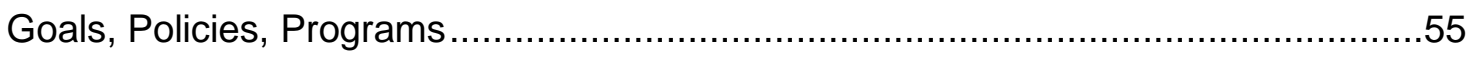

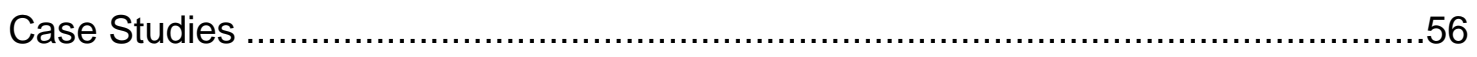

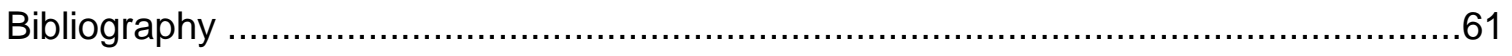




\section{List of Tables}

Table M-1: Population History and Forecasts .....................................................18

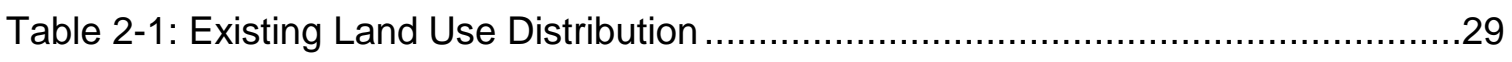

Table 2-2: History of Housing Construction .............................................................

Table 2-3: Land Use Diagram Distribution ................................................................34

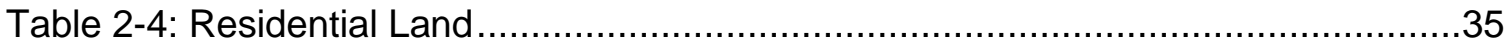

Appendix D: Goals, Policies, and Programs Table …….............................................56 


\section{List of Figures}

Figure M-1: Aerial Photo of McFarland …................................................................ 4

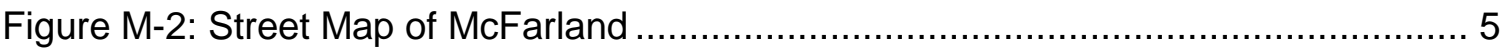

Figure M-3: 2010 Population Pyramid...............................................................19

Figure M-4: 2030 Population Pyramid...................................................................19

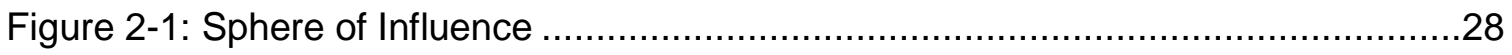

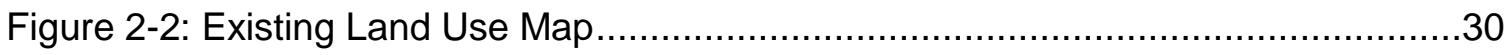

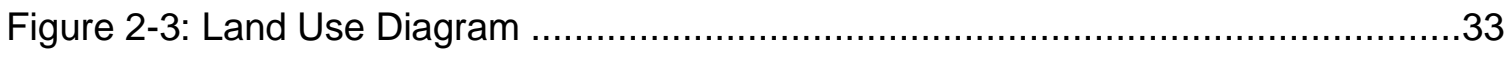

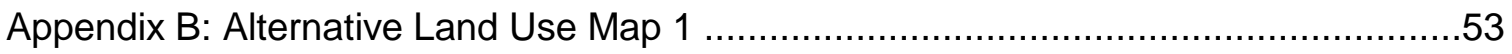

Appendix C: Alternative Land Use Map 2 ……....................................................54 


\section{Methods}

\section{Introduction}

This project is a land use element update for the City of McFarland. This land use element includes a land use diagram, land use standards, and goals, policies, and programs. The purpose of the project is to help guide the allowable location and density of different land uses for the future of the city. Also, the goals, policies, and programs are intended to assist city staff, city council, and the planning commission in how they approve new development proposals.

This project included technical tasks and community outreach tasks. Technical tasks for this project included conducting a land use survey, creating land use maps with Arc GIS, analyzing land use elements of other cities, and forecasting land need. Community outreach tasks included forming a General Plan Advisory Committee (GPAC), facilitating three GPAC meetings and two public workshops, and conducting outreach at a Cinco de Mayo festival. My role for the project focused on completing each of these tasks and incorporating changes which city staff wanted to be made.

\section{Purpose}

A General Plan is a road map for future growth for a jurisdiction and a land use element is central to ensuring that the road map is carried out. This element indicates which land uses are allowed in particular areas of a jurisdiction and the allowable density and intensity of buildings within each land use. The purpose is to provide a cohesive vision for how new residential and commercial developments will connect with one another and with services such as parks and schools. An important part of connecting land uses to one another is ensuring that adjacent land uses are compatible with each 
other. For instance, industrial uses and residential uses are rarely compatible with one another due to noxious substances and/or noises that are often generated by industrial uses.

In addition, a land use element is an informational tool for decision makers to use in approving, denying, and shaping new growth. In the process of approving new development, city officials and staff can utilize goals, policies, and programs of a land use element to help determine the demands they make upon developers. City officials and city staff can make demands such as park land dedication, right-of-way dedications, improvements to infrastructure and monetary dedications to other public services. It is important to find a balance between forcing developers to provide amenities as reimbursements for impacts of their respective developments and making too many demands as to make development prohibitive.

A land use element indirectly regulates the form and use of future development. In order to implement this element, a zoning map must be amended to address any inconsistencies between these two maps. A zoning map specifically outlines the allowable uses, size and location of development for each land parcel in a city.

\section{Setting}

McFarland, CA is a small city surrounded by farmland in Kern County. It is approximately 20 miles North of Bakersfield and 3 miles South of Delano. The city has been experiencing significant population growth in the past decade. Between 2000 and 2010 , the number of residents increased from 9,618 people to 12,707 people; a 32 percent rate of growth (2000 U.S. Census, SF 1, DP-1). A significant portion of the population consists of Latinos who work on farms. 91.5 percent of the population was Latino in 2010 (2010 U.S. Census, QT-PL). Of the 3,950 jobs in 2009, 56 percent of these were in the agricultural sector (Longitudinal Employer-Household Dynamics). The 
city grapples with poverty as indicated by the median income of $\$ 24,190$ in 2000 (2000 U.S. Census, SF 3, QT-P32). One indicator of this poverty and blight is the numerous vacant buildings in the "Downtown District" which are former businesses.

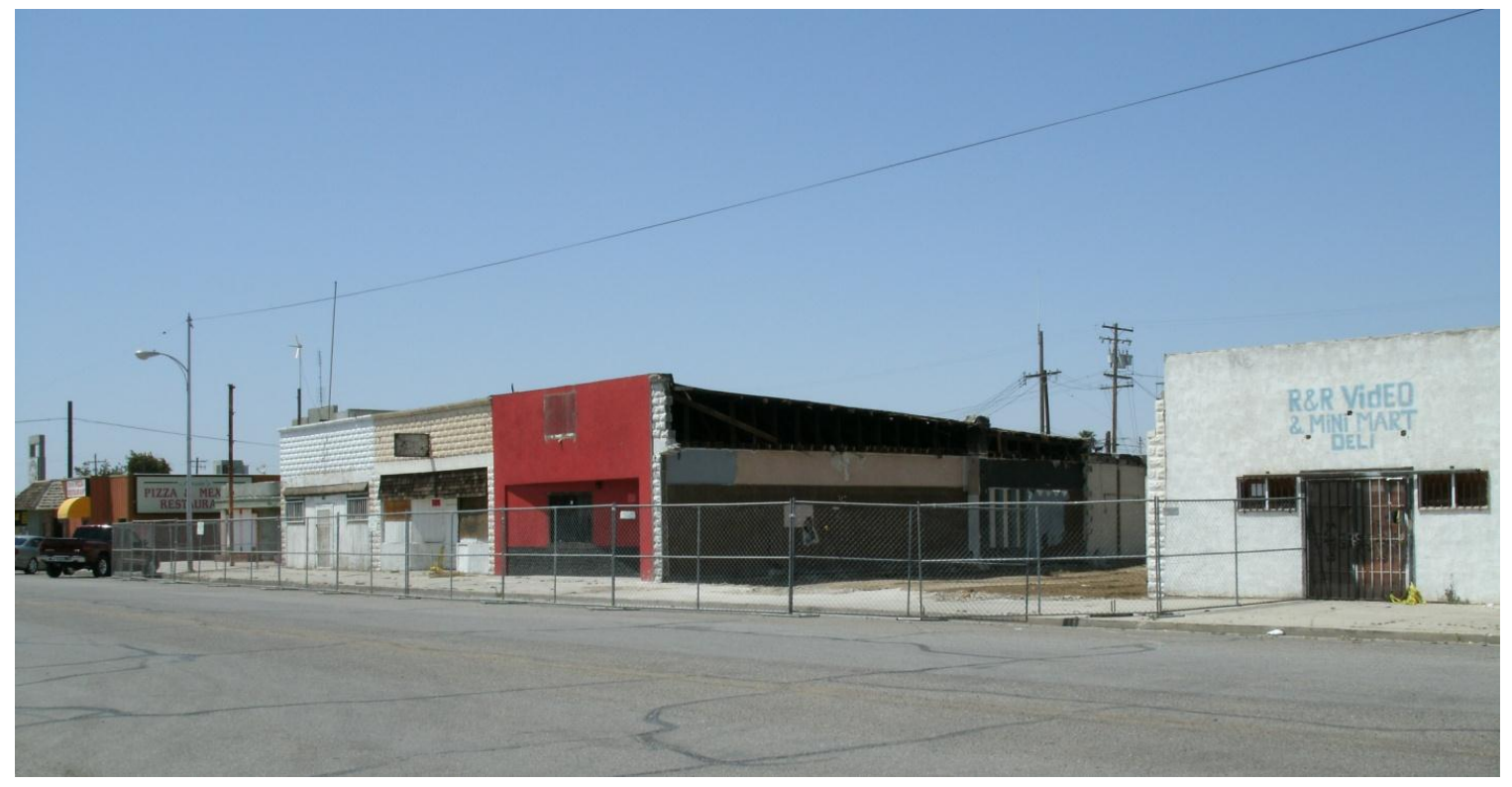

The "Downtown District" of McFarland.

Highway 99 splits the city into two sections. A majority of the community facilities and businesses in the city are located on the West side of Highway 99. This presents a major issue since residents on the East side have access to few services and stores and must travel to the West side for some of these services when there are only three bridges which cross Highway 99 and connect the East and West sides. Thus, in addition to containing few stores and services, the East side lacks accessibility to the West side which contains more of these amenities.

Another issue the city faces is that a portion of the eastern half of the city is in a floodplain. The city can be held liable for approving development in a floodplain. Also, homeowners and business owners in the floodplain typically have to pay significantly higher homeowners' insurance. 
Figure M-1: Aerial Photo of McFarland

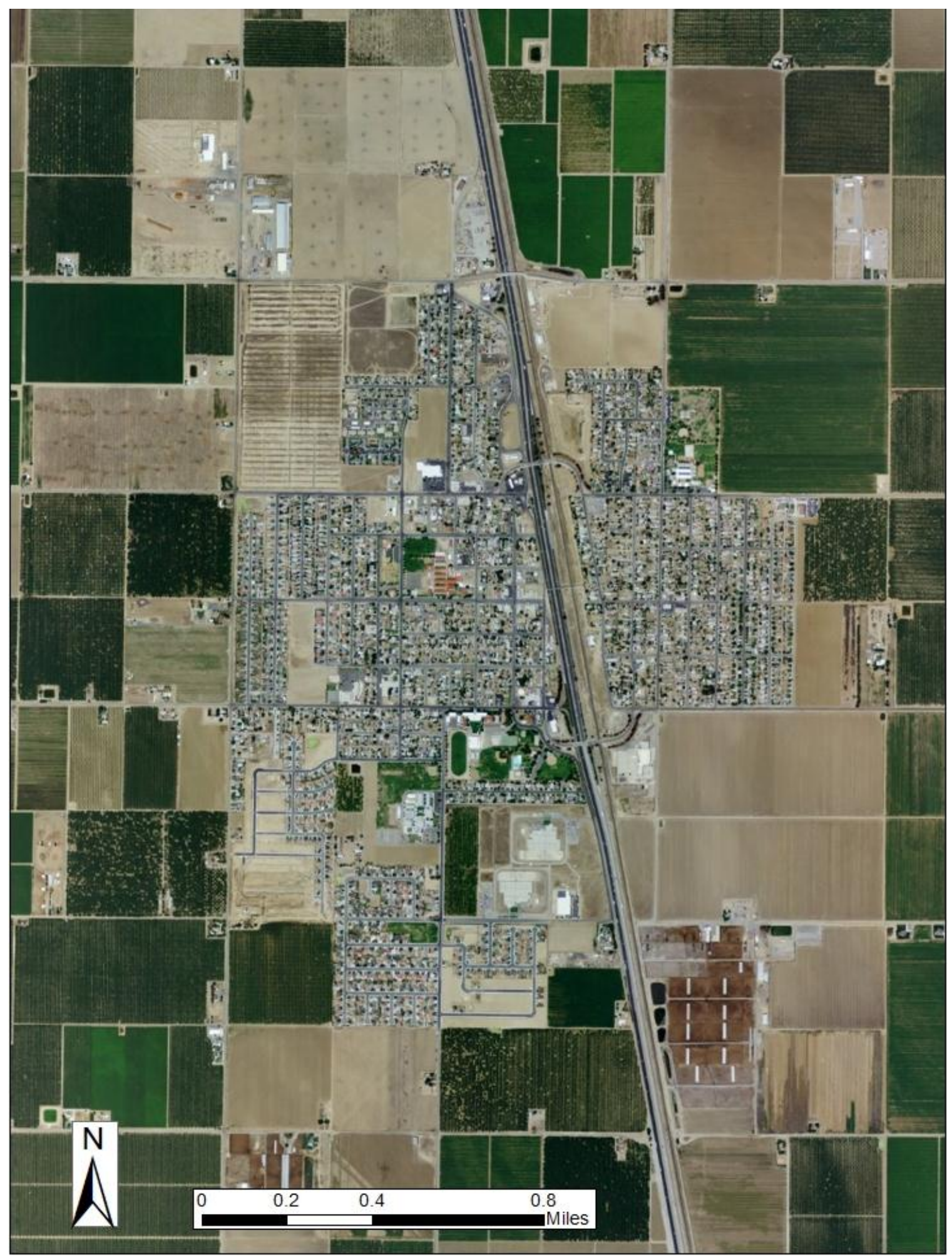


Figure M-2: Street Map of McFarland

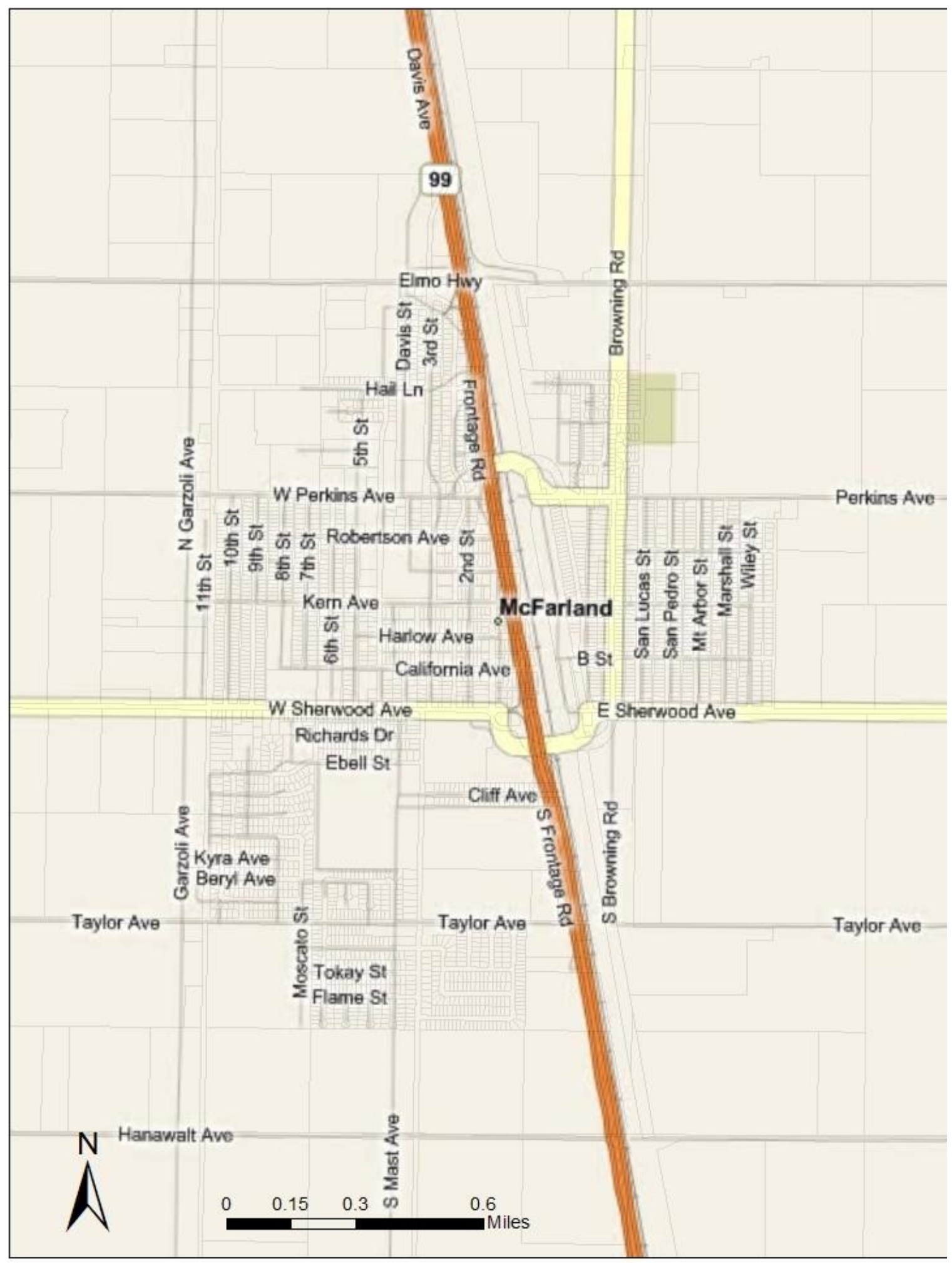




\section{Planning for Latinos}

Since a large majority of the residents in McFarland are Latino, special attention will be given to planning for a Latino community. Myers (2001) recognizes a trend in decreasing construction of multiple-family dwellings and an increasing proportion of Latinos in California and recommends that cities plan for the creation of more multiplefamily dwellings to accommodate a growing population of relatively poor Latinos (Myers, 2001 , p. 388). A crucial way of planning for Latinos is creating compact walkable communities. Development which includes small lots, compact neighborhoods, public spaces and parks can potentially improve the desirability of people walking in a particular community. Latinos spend more time in parks than Anglos or Blacks and are often prolific gardeners where community gardens are available (Stephens, 2008). As a result, this land use element will particularly look to the potential of planning for compact development with supple open space and multiple-family dwelling units.

Perhaps more important than identifying ways to accommodate Latinos in McFarland is to allow them (and other City stakeholders) to explain how the updated land use element can suit their needs and desires. Making the planning process inclusive potentially accommodates cultural diversity by allowing stakeholders to identify how planning can support their respective ethnicities.

\section{Background}

\section{Planning Process}

This project makes use of rational and consensus building methods. In rational fashion, population and housing growth were forecasted and then used to create future land use alternatives. Criticisms of the rational method are that it does not explicitly 
provide stakeholders with inherent assumptions and allow them to make decisions and that it does not provide a clear vision for the proposed future (Berke et al., 2006, p. 48). As a result, community stakeholders were provided with the assumptions of the land use forecasts and of the land use alternatives. Then these stakeholders collaboratively evaluated these land use alternatives in an attempt to build a consensus regarding the preferred future land use map. The second criticism of rational planning of providing a clear vision was not addressed. The scope of this project does not include threedimensional visualizations to depict the proposed futures of the different land use alternatives.

\section{Research}

Research for this project covers six areas: state requirements, regional guidance, case studies, community participation methods, forecasting methods, and alternative growth scenarios methods. State requirements and regional guidance are addressed in this section. Case studies are addressed in the Appendices section of the document. Methods for community participation, forecasting, and alternative growth scenarios are addressed in subsequent sections.

\section{State Requirements}

The California Office of Planning and Research (OPR) requires a land use element to include a land use map, a description of the distribution and location of the different land uses, and the allowable extent of the buildings located within these uses (Office of Planning and Research, 2003). Distribution refers to a depiction of the number of acres of each land use in the city and the percent of each land use compared to the total number of acres in the city. The extent refers to the maximum number of housing units per acre or the maximum floor area ratio (FAR) for commercial and industrial 
buildings. Extent also refers to the allowed width, length and height of each building depending on the designated land use and the size of the parcel.

In addition, a land use element must identify the location of future solid waste sites if applicable and be consistent with the circulation element (Office of Planning and Research, 2003). Consistency with the circulation element entails that roadways can service population densities which the land use element allows for. Since the City of McFarland is currently hiring consultants to update the circulation element, it is crucial that city staff coordinate with these consultants to ensure that the circulation element is consistent with this document. It is important that the circulation element plans for improving transportation infrastructure where necessary to accommodate for increased population densities in areas of the city which the land use element plans for. As other elements of the General Plan are updated, the city (and consultants if applicable) should make sure that these elements are consistent with each other and particularly with the land use element.

\section{Regional Guidance}

McFarland is a member of the Kern Council of Governments (Kern COG). Kern COG provides guidance, particularly regarding transportation, to the numerous municipalities within Kern County to foster decisions that take into account regional considerations. Kern COG completed the Regional Blueprint in 2008 using input from several public workshops throughout Kern County. After providing meeting participants with different alternative growth futures, a majority of the participants chose the alternative which included a moderate increase in compact development (Moore et al., 2008). Participants in this process also identified the principles of providing a variety of housing choices, more affordable housing, preserving farmland, expanding mobility options, enhancing parks and recreation, and managing growth to avoid sprawl. 
Although McFarland is not required to follow these principles, including many of these principles in the General Plan makes the city more competitive for receiving grants from Kern COG.

Kern COG also serves as a Metropolitan Planning Organization (MPO) and as such, is in charge of creating greenhouse gas reductions and corresponding policies with the oversight of the California Air Resources Board (CARB) to comply with SB 375. SB 375 requires CARB to set emissions reduction targets for each MPO. CARB has set the target of a 10 percent reduction in emissions for Kern County (http://www.arb.ca.gov). Kern COG plans on completing a Sustainable Communities Strategy (SCS) to implement these reductions which will provide guidance for local municipalities in creating land use and circulation plans that reduce greenhouse gas emissions for each municipality. Again, although it will not be a requirement for McFarland to follow the SCS, it will make the city more competitive to receive various funding from Kern COG if land use and circulation plans and policies are in line with the SCS. The San Joaquin Valley Blueprint (which Kern COG and seven other councils of governments collaborated to create) has already identified the following strategies to be included in a SCS: a range of housing choices, walkable neighborhoods, a mixture of land uses, infill development, compact buildings, and to preserve farmland

\section{(http://toolkitvalleyblueprintorg.alias.strangecode.com/home).}

\section{Sustainability}

Numerous communities throughout the state are emphasizing the importance of sustainability. The common notion of sustainability refers to reducing harmful environmental impacts. However, in order to advance sustainability, a plan should address the values of ecology, economy, equity, and livability (Berke et al., 2006, p. 38). This notion of sustainability recognizes the competing interests involved in planning and 
the importance of addressing each of these interests' concerns in creating a plan that sustains and thrives through time. Focusing on one of these values to the detriment of the others potentially loses stakeholder buy-in to the plan.

\section{Community Participation}

\section{Overview}

Community stakeholders collaborated to help create a vision for the future of McFarland. This vision formed the foundation for the goals and policies in this document. In addition their feedback guided the creation of the land use diagram which indicates where future development can occur and the allowable intensity and use of development relative to location.

Major themes from community stake holders included:

- A revitalized and vibrant mixed-use downtown.

- A more attractive city.

- An increase in the number of businesses.

- A greenbelt system.

\section{Outreach}

A major concern for community participation meetings is having a group of participants who are representative of the community. In the past ten years, community participation meetings in McFarland typically have attracted few participants. When the Kern Council of Governments held a meeting in McFarland on October 30, 2007 for the Regional Blueprint Plan, for instance, 3 residents and 3 city officials showed up to the meeting (Moore et al., 2007, p. 7). Efforts to attract a larger segment of the population in the community outreach process for this document were slightly successful. 
Methods employed to attract community stakeholder input included: forming a General Plan Advisory Committee (GPAC), setting up a booth at the Cinco De Mayo Parade, passing out brochures, advertising public workshops in the local newspaper, and providing food at public workshops. Forming a GPAC influenced six stakeholders to be vested in the process. From the outset, we had the same number of people on the GPAC who committed to coming to future meetings as the number of people who attended the 2007 Kern COG meeting. In addition, having GPAC members who continued to come to subsequent meeting was very valuable in how we could build off of previous meetings with everyone on board with what stage the process was in.

GPAC Members:

mayor Manuel Cantu

Vidal Santillano: city council member.

Robert Newkirk: planning commissioner.

Milton Mar: planning ommissioner.

Santos Garza: Retired. Former school board member.

Roy Gonzalez: Realtor.

Lindolfo Martinez: Contractor.

\section{Meetings}

\section{GPAC Meeting 1}

The first General Plan Advisory Committee (GPAC) meeting provided committee members with an introduction to each other, to a General Plan, a land use element, and the purpose of the GPAC committee. The primary purpose of the GPAC committee is to help guide the formation of the goals, policies, and land use diagram of the element. A 
major component of this role is helping determine how to conduct community outreach and public workshops and then how to translate community feedback into goals and policies for the plan.

This meeting also consisted of asking committee members to first write down on paper and then discuss two questions: What do you like about McFarland? What do you want to change about McFarland? The dominant theme during this discussion was beautifying the city.

Feedback provided during this meeting included:

- Beautifying the city to make it more desirable for businesses to develop here. Specific ideas for beautifying the city included demolishing derelict buildings and installing lighting fixtures on streets.

- $\quad$ Creating a nice downtown commercial corridor. One potential site identified is Kern Ave. where the previous Downtown District is located.

- Avoid becoming a bedroom community with few businesses and numerous houses.

- Utilize the railroad by locating new industrial and commercial development adjacent to it.

\section{Cinco De Mayo Festival}

The Cinco De Mayo Parade conveniently occurred a few days before the first public workshop. City staff took advantage of this opportunity by setting up a booth at this festival, handing out brochures regarding the workshop, asking people what they wanted to change in their community, and collecting surveys. Unfortunately, these efforts only attracted a couple of people to the first public workshop and only a couple of 
surveys were received. The lengthiness (two pages) and difficulty of some of the questions likely explains the low response rate for the surveys.

Feedback received during this festival included:

- The city needs some large retail stores to provide jobs and so that residents do not have to drive to Delano or Bakersfield to shop for groceries and other items.

- Old and abandoned buildings should be torn down to improve the appearance of the Downtown District.

\section{Public workshop 1}

There were a total of 8 community members present at the first public workshop. Meeting participants included the mayor, two planning commissioners, a GPAC member, the director of the McFarland Parks and Recreation Department, and three general residents. After everyone helped themselves to food and we introduced ourselves, I provided a Power Point presentation briefly introducing the purpose of a land use element and the things a General Plan can plan for (i.e. the location of a new park, downtown street improvements). Then, using steps recommended by Sanoff (2000), participants began brainstorming a vision for McFarland's future and these ideas were recorded on a large flip-chart (Sanoff, 2000, p. 81). Recording on the flip-chart let participants know that their ideas were being heard and helped participants keep track of generated ideas. However, these ideas were not summarized at the end of the activity as recommended by Sanoff to ensure that ideas were correctly heard and to reinforce accomplishments made towards creating a shared vision (Sanoff, 2000, p. 82). This method of summarizing comments was used in the subsequent GPAC meetings and public workshop. 
Feedback received during this meeting included:

- People like the fact that McFarland is a small town.

- The need for a walkable community with a trail system, a mixture of land uses, and possibly a plaza nearby a central commercial area.

- Increase public services and economic development on the East side of the City.

- Plant trees and install lights in areas of particular commercial significance.

\section{GPAC Meeting 2}

The purpose of this meeting was to have General Plan Advisory Committee (GPAC) members develop strategies to move in the direction of the goals developed so far. Sanoff (2000) recommends this tactic of having meeting participants create strategies to implement goals which were previously identified by community stakeholders. There was strong support from GPAC members for the strategy of focusing street improvements (i.e. lights, trees, painting street lines) at freeway exits, Frontage Rd., parks, and at the Downtown District. Another strategy that received wide agreement was for city planning staff to continually advise the city council and planning commission in creating conditions of approval for new development and for ensuring that these conditions are implemented.

In addition to creating strategies, GPAC members used maps signifying city limits, sphere of influence, and parcels under Williamson Act contract to provide initial recommendations on where to allow new urban growth. Williamson Act parcels were signified because this poses a very significant constraint to development as a large fine must be paid to prematurely cancel a Williamson Act contract. City staff advised GPAC members to focus first on identifying urban growth on land which is not under a Williamson Act contract. In particular, we focused on identifying where to locate future commercial and manufacturing development. GPAC members generally agreed that 
land just southeast of city limits and North of city limits along Highway 99 provided good locations for both commercial and manufacturing development. They reasoned that these locations provided good visibility from Highway 99 for commercial businesses and good access to both the Highway and the railroad for manufacturing establishments.

\section{GPAC Meeting 3}

In this meeting GPAC members were provided with two land use alternatives (see Appendices B and C) to determine the extent to which they wanted McFarland to grow. Both land use alternatives incorporated recommendations received from the GPAC members in the second GPAC meeting. When considering the most preferred future growth alternative, a decision should consider a number of different possible outcomes instead of only the most likely outcome (Hopkins, 2001, p. 73). A recommendation by Berke et al. (2006) to include land reserves for urban development was utilized since land needs are difficult to accurately forecast and demand for development may be stronger than forecasted. The three GPAC members in attendance wanted to error on the side of designating more land for urban uses than necessary to help give the city more latitude in annexing land. Aligning with this sentiment, Alternative Land Use Map 1 was generally liked by the members. They agreed that designating land for urban reserve could avoid designating far too much land for urban purposes and allowing for leap frog development. The GPAC members also generally liked how land uses were distributed on Alternative Land Use Map 1. However, one member recommended designating more land for commercial along Garzoli Ave. since he thought this would become a major corridor in the future.

In addition, the GPAC members came to general agreements on how to change land use designations for land within the existing city limits. For instance, a mixed use zone was recommended for an area just South of the existing commercial corridor along 
Perkins Ave. (see Figure 2-3: Land Use Diagram). Corridors adjacent to Highway 99 were suggested for commercial and highway commercial use. A commercial corridor was also recommended for the portion of Kern Ave. which is East of Highway 99.

\section{Public Workshop 2}

In attendance at this workshop were five general residents, one GPAC member, and one planning commissioner. In this workshop, city staff presented the proposed Land Use Diagram and described how previous input from stakeholders had influenced particular components of the Diagram. Then participants were asked to provide feedback regarding the Diagram. In general, participants liked the Diagram. One

participant recommended making $2^{\text {nd }}$ Street (between Sherwood Ave. and Perkins Ave.) as a new "Main Street" for creating a downtown for McFarland. This participant recommended designating this corridor for commercial use and planting Palm trees and potentially other street improvements to help build this area up as the "Main Street" for McFarland. Other participants in the meeting generally liked this suggestion. Interestingly, most of the participants at this workshop had not been to the previous workshop and many of the comments they provided echoed comments in the previous GPAC meetings and the previous public workshop. One participant stressed the importance of providing for more services and economic development on the East Side. Another participant described the constraint mentioned in previous meetings that a new sewer needs to be constructed to connect the East side to the Waste Water Treatment Plant in order to allow for new growth on the East side. Another participant commented that the city needs to take account of any plans by CalTrans to change the location of highway interchanges in the Land Use Diagram. 


\section{Limitations}

A very significant limitation of the outreach efforts for this project is the lack of utilizing Spanish speakers to go out into the community to elicit feedback to help guide this project. As mentioned earlier, the city had a great opportunity in the Cinco De Mayo festival to receive feedback from residents and to attract them to the upcoming public workshop. However, Spanish speaking translators were not utilized by the city to receive this feedback or to attract residents who cannot speak English. About 15 percent of the population in McFarland above the age of 4 cannot speak English well (2000 U.S. Census, SF 3, P19). Although 15 percent does not seem very significant, there were quite a few people at the Cinco De Mayo festival who were unable to speak to me in English.

Residents who could not speak English were given fliers and surveys advertising the public workshop in Spanish in hopes they would fill them out and/or come to the workshop. Unfortunately few people came to the workshop as a result of outreach at the festival and few surveys were received. If a Spanish translator had assisted the city in getting feedback at this festival, there could have been significantly more surveys received and attendants at the public workshop.

\section{Projections}

\section{Population}

The cohort method was used to project the population in McFarland for 2030. This method takes into consideration changes in birth, survival, and migration rates. Also, it provides age and gender specific data for 5-year time intervals. Age and gender specific data is useful for determining particular services useful for particular population demographics. A shortfall of this method is that it uses data from Kern County for the 
birth, survival, and migration rates and Kern County may not represent McFarland in regards to these variables.

As Table M-1 indicates, the population in McFarland has steadily increased since 1970. Notice that the population also continues to increase by a larger amount with each new decade. Also, the forecasted increase from 2010 to 2020 is much larger than any increase yet experienced by the city. However, due to the national economic crash which happened between 2000 and 2010, population increases were smaller than could be expected. Residential tract developments which were in the works for the city during this time fell through and the population did not grow as expected as a result.

Table M-1: Population History and Forecasts

\begin{tabular}{|c|c|c|}
\hline Year & Population & Change from Previous Decade \\
\hline 2030 & 27,826 & 7,905 \\
\hline 2020 & 19,921 & 7,214 \\
\hline 2010 & 12,707 & 3,089 \\
\hline 2000 & 9,618 & 2,613 \\
\hline 1990 & 7,005 & 1,867 \\
\hline 1980 & 5,138 & 961 \\
\hline 1970 & 4,177 & \\
\hline
\end{tabular}

As Figures M-3 and M-4 indicate, a larger portion of the population is projected to consist of people older than 50 and younger than 15. These changes could have implications on the types of services useful for residents. For instance, a senior center and/or senior housing options may be particularly useful as increasingly more people in the city are older than 50 . Also, additional school facilities and/or park facilities could be particularly useful for an increasing population of people younger than 15 . 
Figure M-3: 2010 Population Pyramid

\section{McFarland Population Pyramid}

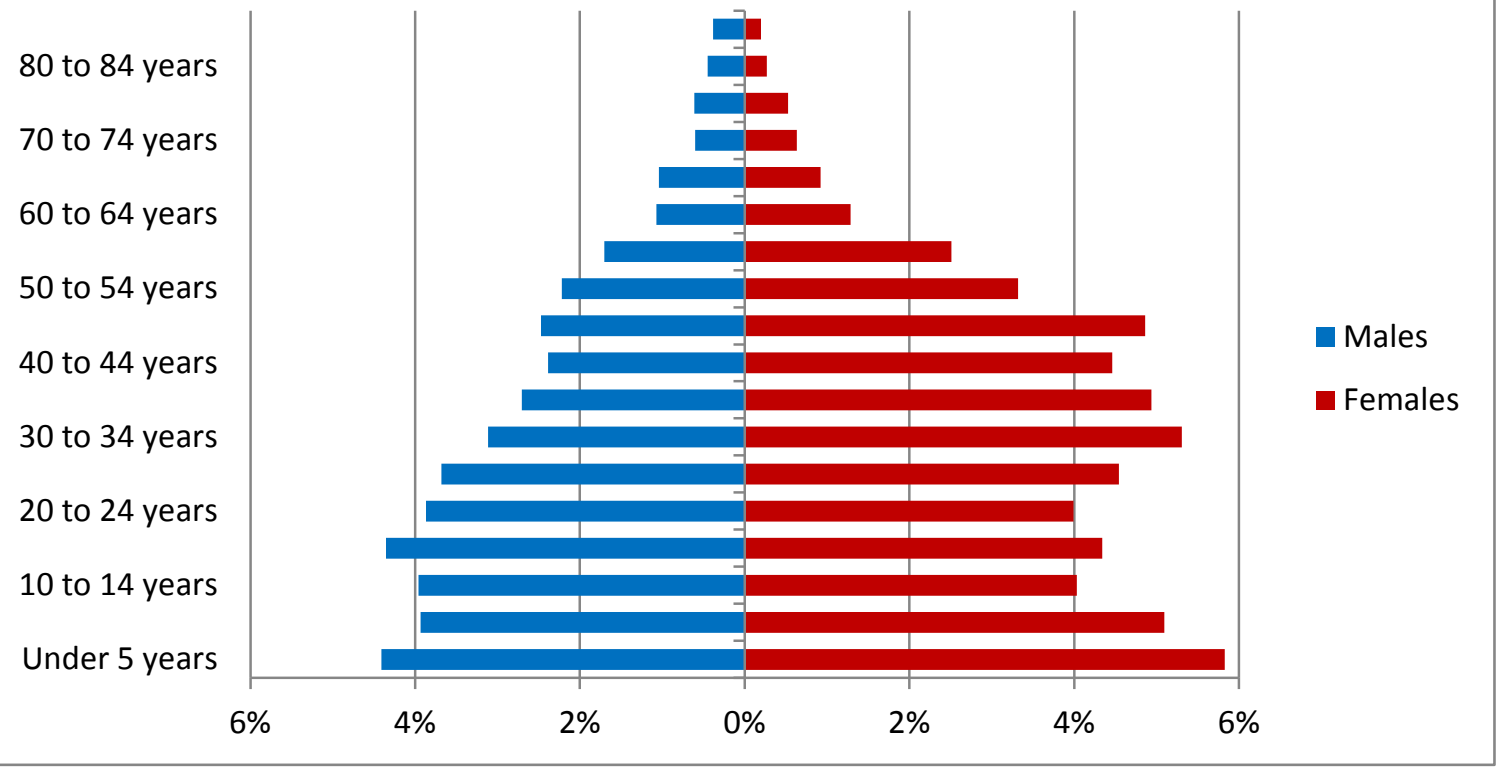

Source: Projections by Jeff Ballantine using 2000 U.S. Census, SF 1, Table DP-1.

Figure M-4: 2030 Population Pyramid

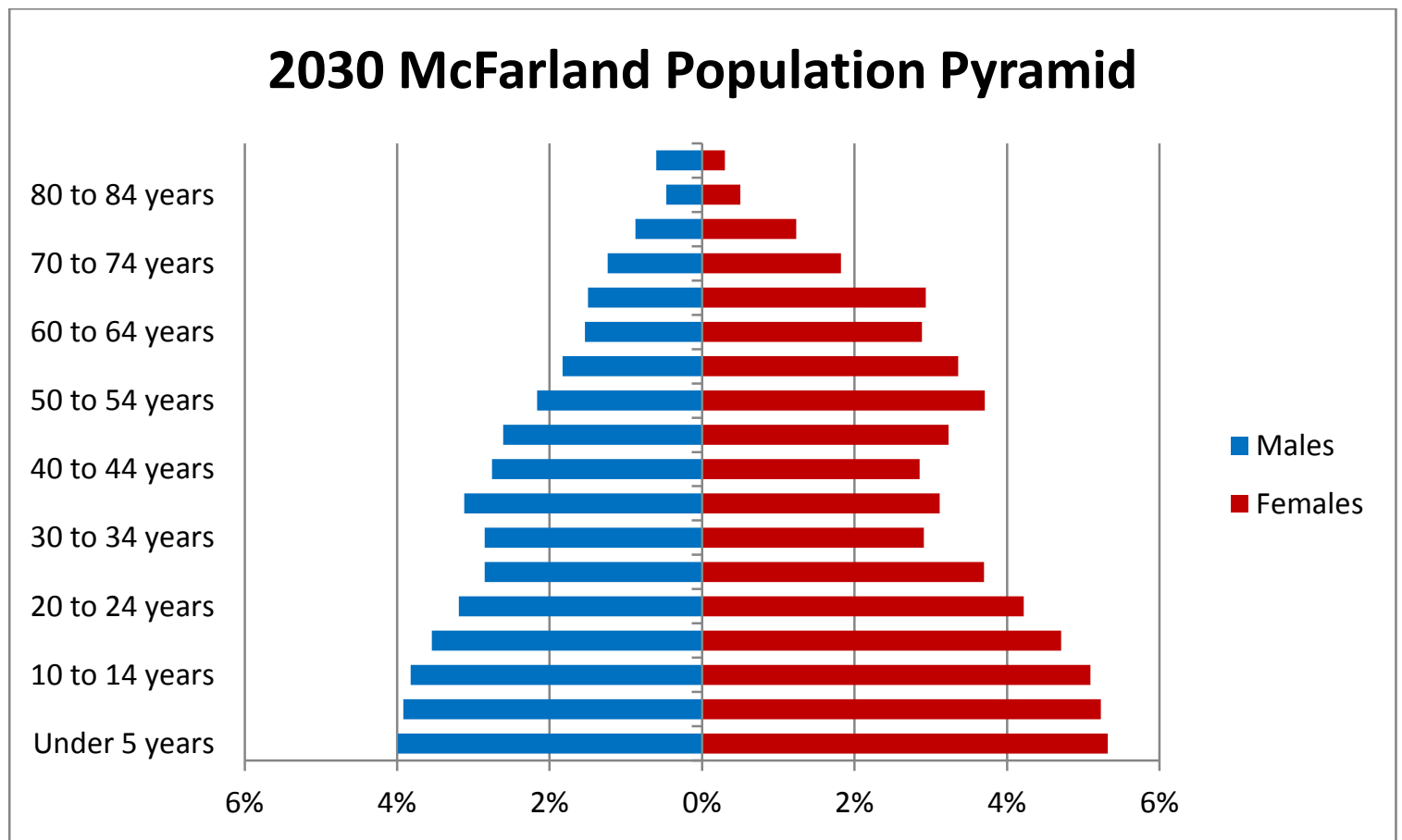

Source: Projections by Jeff Ballantine using 2000 U.S. Census, SF 1, Table DP-1. 


\section{Residential Land}

In order to forecast the number of housing units which will be needed to accommodate future population growth, the average household-size method was used. In this case, this method entails dividing the projected 2030 population $(27,826)$ by the 2010 average household size (4.89) and then making some adjustments to provide for a vacant housing stock and to account for the loss of housing units over time (Berke et al., 2006, p. 407). The resulting forecast for households in $2030(5,691)$ is increased by five percent to provide a vacant housing stock to allow for variations in residential mobility. This figure $(5,976)$ is then increased by two-tenths of a percent of the number of housing units in 2010 to account for loss in housing units over time due to such things as fire, conversion to commercial uses, or general degradation. Finally, this result $(5,981)$ is subtracted from the number of housing units in $2010(2,683)$ for a resulting 3,298 additional housing units needed by 2030 . Thus, the land use element needs to provide enough land to accommodate the construction of at least an additional 3,300 housing units during the planning period (2010 to 2030).

Once the housing growth needed to support population growth was obtained, the land needed to support the housing need was calculated. Existing average building densities for low density residential (5 units/acre), medium density residential (10 units/acre), and high density residential (20 units/acre) areas were used to calculate the number of acres needed to support a certain number of units depending on the relative share of low, medium, and high density land. For instance, if existing trends continued and low density residential consisted of 72 percent of residential land, medium density at 24 percent and high density at 4 percent, then 560 additional acres would be needed to accommodate 3,300 new units. 
The Regional Housing Needs Assessment (RHNA) for the city determined by Kern COG is an additional 775 units between 2008 and 2013. Of these 775 additional units at least 20 percent should be multi-family and 5 percent mobile home. The planning period for this Land Use Element is four times as long as the planning period for the RHNA target and accommodates for more than eight times as many units as the RHNA target. Additionally, of the 6,310 additional units accommodated for in this Plan, almost 70 percent are multi-family units. Thus, this Plan satisfies the minimum targets of the Regional Housing Needs Assessment.

\section{Commercial and Industrial Land}

In order to calculate the minimum commercial acreage needed in the city by 2030, the ratio of population to commercial land in 2010 was applied to the projected population in 2030. Thus, the population in $2010(12,707)$ per the number of commercial acres in 2010 (38) was divided by the projected population in $2030(27,826)$. As a result, the land use diagram shall designate at least 78 acres for commercial land. This method was similarly used to calculate the minimum industrial land needed by 2030 and resulted in a need of 35 acres. The 2002 Farmersville, CA General Plan identified this method as useful for projecting minimum commercial and industrial land need (Collins \& Schoettler, 2002).

An issue with this method is that the existing ratio of population to commercial acreage in use may not be a desirable ratio for the city. In fact, in the case of McFarland, residents typically want a lot more businesses and commercial acreage in use than there currently exists. Many residents travel to Delano or Bakersfield in order to do their shopping and could use more shopping options in McFarland. Another issue is the extent to which the tax base of the city can support additional businesses. No matter 
how the city designates land for commercial use, it ultimately depends on whether or not commercial investors think that the city can support their establishments.

This method was used for its simplicity. Another possible method is projecting the job growth and then calculating the additional commercial land needed to support that job growth by applying standards of jobs per acre for different industrial sectors.

Potential error with this method is in not knowing the accuracy of the standards used for jobs per acre to translate job growth into commercial acreage needed. When applied to the City of McFarland, this method results in a need of 130 commercial acres by 2030. This seems like a gross overestimate when there are 38 acres of existing commercial acreage in use. If the job growth method is accurate in this case, then population would increase slightly more than two-fold and commercial demand would increase more than three-fold.

\section{Lessons Learned}

This project provided the experience of working for a small municipality in the Central Valley of California which is short on resources and city staff. What does a city do when it is hurting for economic development and has few resources to make improvements to attract development? How can the land use element assist in attracting economic development? Continually confronting this challenging issue was an invaluable experience which required effective facilitation of meetings with stakeholders to identify feasible strategies to attract commercial development.

In working for a small poor city in the Central Valley, the planning staff for the city may not be up to date on the latest methods in the planning field. It is important for a student coming into this setting to be accepting of methods which are not taught by professors and to not assume that what they were taught is always best in every 
circumstance. Methods taught by Cal Poly City and Regional Planning Professors for conducting community outreach differed from how city staff conducted outreach in some instances. In these cases, I would explain the methods I had learned to city staff as options to consider but not with the assumption that these methods were necessarily better than others used. It may be that the methods which city staff uses are more applicable and relevant for the community than what the professors and textbooks espouse.

For instance, while innovative planners promote innovative "sustainable" strategies involving bioswales, bicycle lanes, pedestrian plazas, and renewable energy, many of these strategies are likely not feasible for McFarland. In a city like McFarland, where the city is hurting for any sort of development, making numerous demands upon new development is likely not feasible. In a city like McFarland, where the municipality has little in the way of funds, implementing "sustainable" innovative strategies is likely not feasible. In a city like McFarland, community stakeholders, city staff, and city officials may be so consumed with attracting commercial development that notions of implementing these sorts of "sustainable" strategies may not even be considered. However, the city could certainly improve how it engages community members to increase the participation in future outreach efforts.

This project exemplified the importance of going out into the community and getting feedback instead of asking residents to come to meetings. Completing this task in a predominantly Latino community requires a Spanish translator. Conducting a comprehensive public outreach process that reaches a large portion of stakeholders in a community where few people come to community meetings and where the city is short on resources and staff is particularly difficult. However, a cost-effective strategy is employing a bilingual person to talk with residents at community events, markets, and/or 
walking on the street to ask people what they want for the future of the city and feasible ways in which city staff can make that happen. As the outreach effort process for this document and previous outreach efforts are testaments to, few community members come to community meetings. Thus, if the city truly wants community feedback, city staff needs to go out into the community to ask people for feedback. 


\title{
Land Use Element Updatte
}

\author{
City of McFarland, CA \\ 2011-2030
}




\section{Purpose}

The Land Use Element determines the allowable use of existing and future parcels of land and ensures that adjacent land uses are compatible with one another. The California Governor's Office of Planning and Research (OPR) requires a land use element to include a land use map, a description of the general distribution and location of the different land uses, and the allowable density of the buildings located within these uses (Office of Planning and Research [OPR], 2003). Policies in combination with the land use map provide general guidance on where development can occur, the allowable size of new development, and how development can be used depending upon its location. Taken together, these components of a land use element provide a road map for future development.

\section{Setting}

McFarland, CA is a small city surrounded by farmland in Kern County. It is approximately 20 miles North of Bakersfield and 3 miles South of Delano. The city has been experiencing significant population growth in the past decade. Between 2000 and 2010, the number of residents increased from 9,618 people to 12,707 people; a 32 percent rate of growth (2000 U.S. Census, SF 1, DP-1). A significant portion of the population consists of Latinos who work on farms. 91.5 percent of the population was Latino in 2010 (2010 U.S. Census, QT-PL). Of the 3,950 jobs in 2009, 56 percent of these were in the agricultural sector (Longitudinal Employer-Household Dynamics).

Highway 99 splits the city into two sections. A majority of the community facilities and businesses in the city are located on the West side of Highway 99. As a whole, the city grapples with poverty as indicated by the median income of $\$ 24,190$ in 2000 (2000 U.S. 
Census, SF 3, QT-P32). Another indicator of this poverty and blight is the numerous vacant buildings in the "Downtown District" which are former businesses.

\section{Existing Conditions}

\section{Planning Area}

This land use element focuses upon land within the city's planning area. The planning area consists of a total of 7,220 acres. Of this land within the planning area, there is 1,680 acres of incorporated lands and 5,540 acres of land in the city's sphere of influence (see Figure 2-1). Incorporated land is land which is within the city limits and which the city is responsible for controlling the designation and distribution of land uses. Land within the city's sphere of influence is area which the city does not directly have land use control over but which the city could potentially annex into city limits with approval of the Kern County Local Agency Formation Commission (LAFCO). Although Kern County has jurisdiction over McFarland's sphere of influence, the city can provide comments to Kern County regarding proposed projects within the city's sphere of influence. 
Figure 2-1: Sphere of Influence

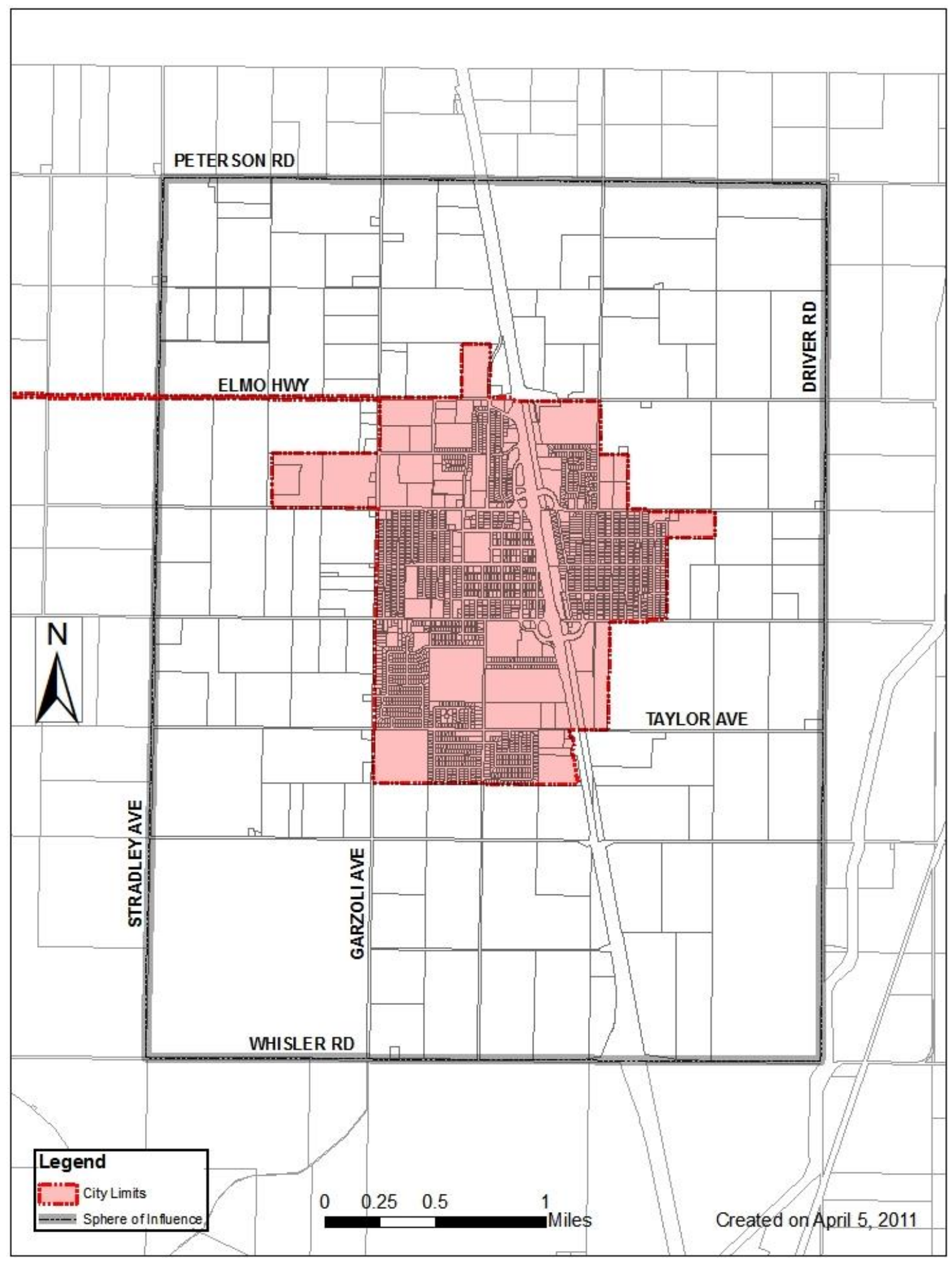




\section{Distribution of Land Uses}

Most of the land within city limits is used for institutional and residential purposes or is vacant (see Table 2-1). Institutional land includes the wastewater treatment plant, sumps, City Hall, and water tanks. As Figure 2-2 demonstrates, the predominant land use on the western portion of the city is low density residential and a significant portion of the land is used for medium density residential on the eastern portion of the city. Commercial land is generally located adjacent to Highway 99 on the western edge of the Highway and along Perkins Ave. West of the Highway. The northwest and southwest portions of the city contain a significant amount of vacant land.

Table 2-1: Existing Land Use Distribution

\begin{tabular}{|l|c|c|c|c|}
\hline \multirow{2}{*}{ Land Use } & \multicolumn{2}{|c|}{ Incorporated Land } & \multicolumn{2}{c|}{ Planning Area } \\
\cline { 2 - 5 } & Acreage & Distribution & Acreage & Distribution \\
\hline Institutional (Except schools) & 723 & $43 \%$ & 723 & $10 \%$ \\
\hline Residential & 394 & $23 \%$ & 394 & $5 \%$ \\
\hline Vacant & 296 & $18 \%$ & 296 & $4 \%$ \\
\hline Agriculture & 83 & $5 \%$ & 5,622 & $78 \%$ \\
\hline School & 78 & $5 \%$ & 78 & $1 \%$ \\
\hline Commercial & 38 & $2 \%$ & 38 & $1 \%$ \\
\hline Open Space & 26 & $2 \%$ & 26 & $0 \%$ \\
\hline Industrial & 17 & $1 \%$ & 17 & $0 \%$ \\
\hline Church & 12 & $1 \%$ & 12 & $0 \%$ \\
\hline Total & 1,681 & $100 \%$ & 7,220 & $100 \%$ \\
\hline
\end{tabular}

Source: 2010 McFarland Land Use Survey. 
Figure 2-2: Existing Land Use Map

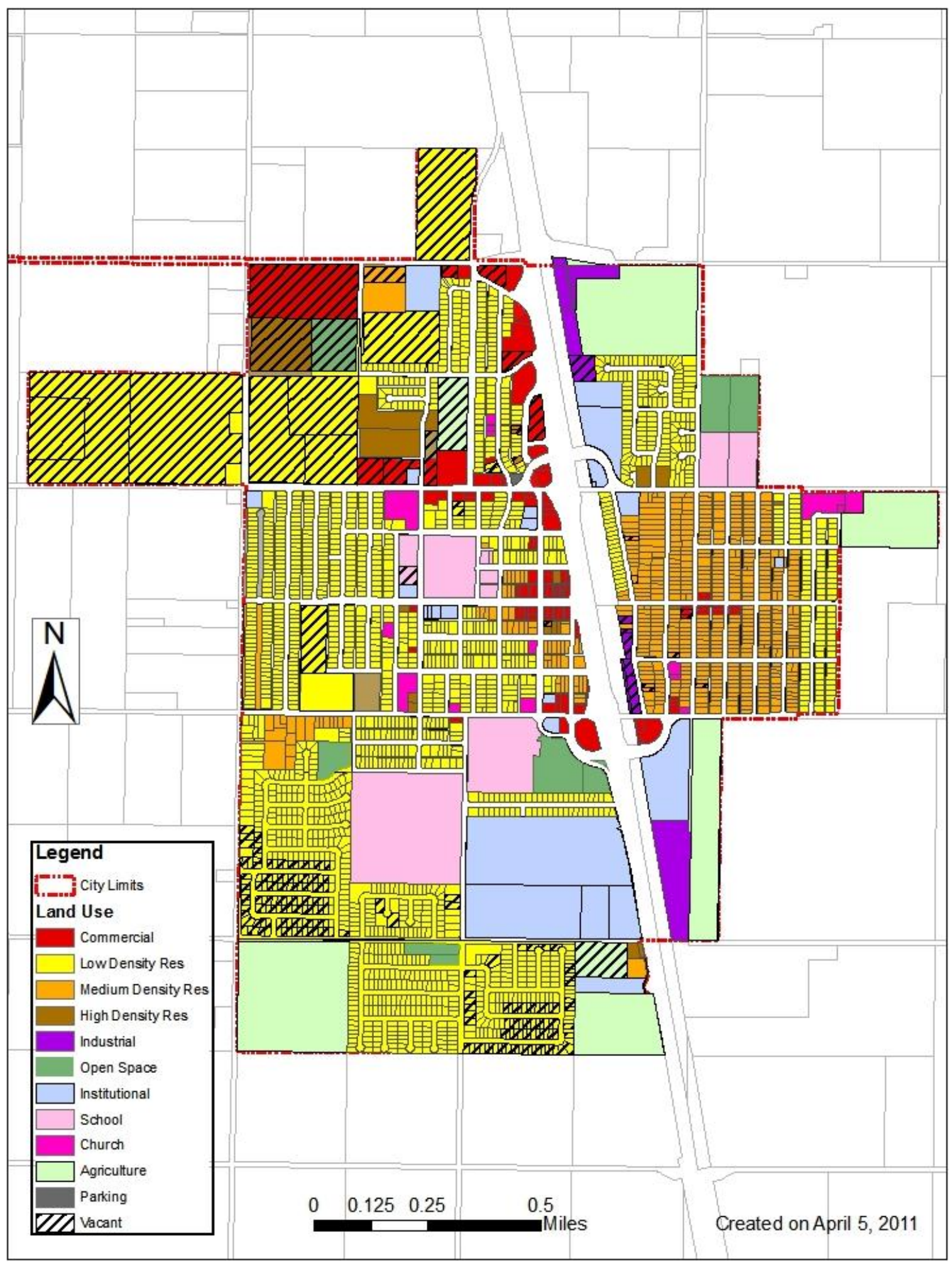




\section{Previous Residential Development}

As Table 2-2 indicates, McFarland witnessed steady growth in housing unit in the last half of the twentieth century. Since 1960, over 300 housing units have been built in McFarland every decade. The largest growth in number of units occurred during these past two decades (2000 to 2010 and 1990 to 2000).

Table 2-2: History of Housing Construction

\begin{tabular}{|l|c|}
\hline Year Structure Built & Number of Housing Units \\
\hline Built 2000 to 2010 & 665 \\
\hline Built 1990 to 2000 & 434 \\
\hline Built 1980 to 1989 & 389 \\
\hline Built 1970 to 1979 & 381 \\
\hline Built 1960 to 1969 & 409 \\
\hline Built 1950 to 1959 & 240 \\
\hline Built 1940 to 1949 & 113 \\
\hline Built 1939 or earlier & 52 \\
\hline Total: & 2,683 \\
\hline
\end{tabular}

Source: 2010 Census, Table QT-PL. 2000 Census, Summary File 3, Table H34.

\section{Land Use Diagram}

The land use diagram provides land use designations for all land within the planning area. This diagram signifies where new development can occur and is used as a resource for reviewing proposed development. Despite a few exceptions, the land use diagram is consistent with the existing land use map and provides additional urban land 
use designations for land within the sphere of influence and for vacant land within city limits. The exceptions include a mixed use district, a highway commercial district, and the designation of vacant land for medium and high density residential use. This diagram was created using policies generated from public input and from physical constraints. 
Figure 2-3: Land Use Diagram

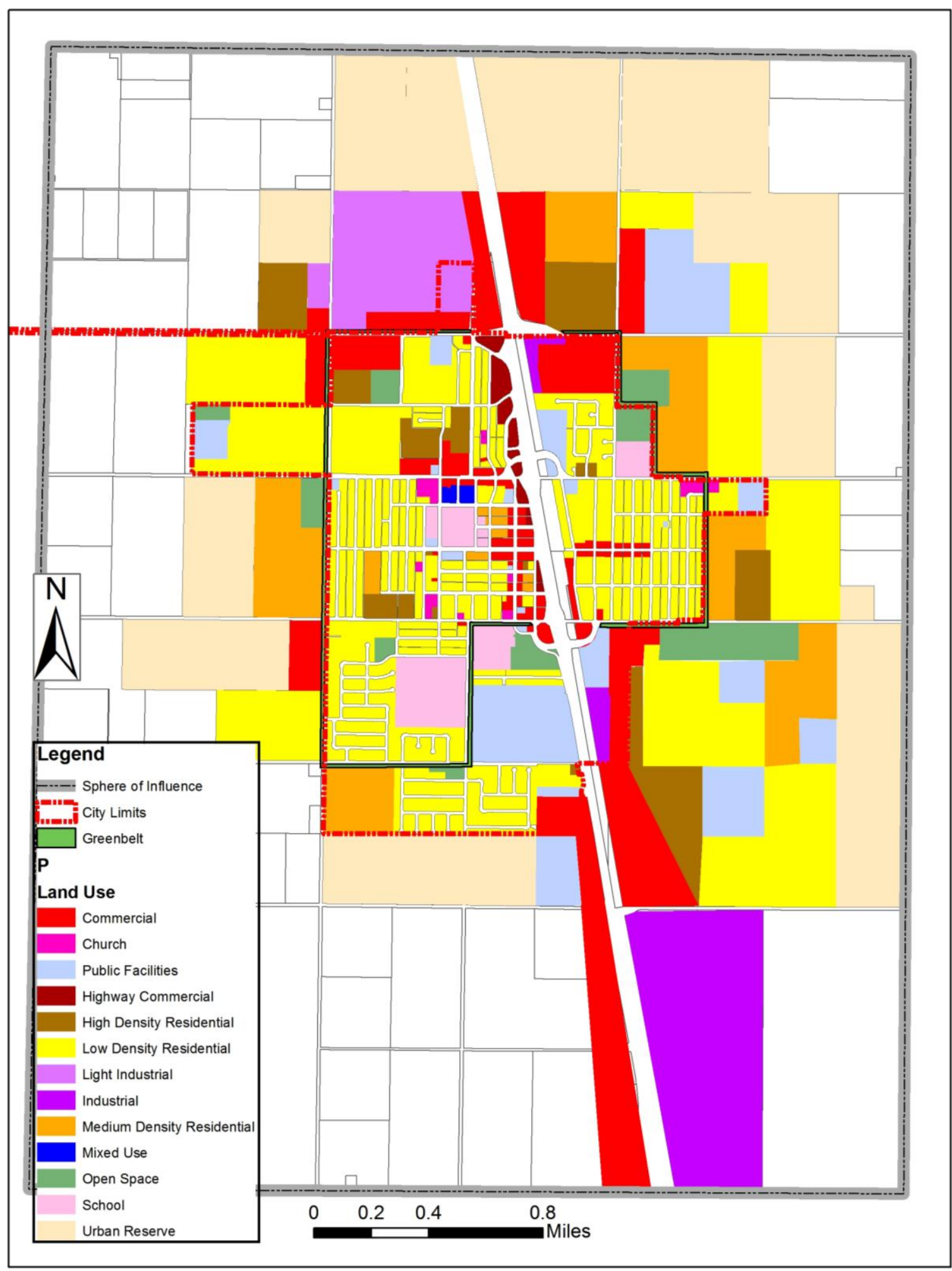




\section{Guiding Policies}

Feedback gathered from community stakeholders during two public workshops and three meetings with the General Plan Advisory Committee (GPAC) indicated the following policies which guided the creation of the Land Use Diagram:

- A walkable community with a trail system and areas with a mixture of land uses.

- More opportunities for commercial and industrial growth adjacent to Highway 99.

- More commercial growth and services on the East side of Highway 99.

- More parks and more recreational opportunities for youth.

Table 2-3: Land Use Diagram Distribution

\begin{tabular}{|l|c|c|c|c|}
\hline \multirow{2}{*}{ Land Use } & \multicolumn{2}{|c|}{ Incorporated Area } & \multicolumn{2}{|c|}{ Planning Area } \\
\cline { 2 - 5 } & Acreage & Distribution & Acreage & Distribution \\
\hline Public Facilities & 801 & $48 \%$ & 893 & $12 \%$ \\
\hline Residential & 394 & $23 \%$ & 1,633 & $23 \%$ \\
\hline Vacant & 296 & $18 \%$ & 0 & $0 \%$ \\
\hline Agriculture & 83 & $5 \%$ & 2,760 & $38 \%$ \\
\hline Commercial & 38 & $2 \%$ & 555 & $8 \%$ \\
\hline Open Space & 26 & $2 \%$ & 121 & $2 \%$ \\
\hline Industrial & 17 & $1 \%$ & 409 & $6 \%$ \\
\hline Church & 12 & $1 \%$ & 12 & $0 \%$ \\
\hline Total & 1,681 & $100 \%$ & 7,220 & $100 \%$ \\
\hline
\end{tabular}




\section{General Plan Buildout}

This section demonstrates that the land use diagram accommodates enough land to support projected population growth for the city for the year 2030.

\section{Growth Projections}

According to the cohort method, the city is projected to have 27,820 residents in 2030 .

This method uses rates of birth, death and migration for Kern County and applies them to 2000 US Census population data for the City of McFarland and Kern County to project the population of McFarland for future years. More land is needed for residential, commercial, and industrial purposes as well as for park space and for schools in order to support an addition of over 15,000 residents.

\section{Residential Land}

In order to accommodate projected population growth at the existing average household size (4.89 people per household), the city needs an additional 3,300 housing units by 2030. Table 2-4 demonstrates that the designated residential land in the future land use map exceeds this need by accommodating for an additional 14,174 housing units.

Table 2-4: Residential Land

\begin{tabular}{|l|c|c|c|}
\hline $\begin{array}{l}\text { Residential } \\
\text { Densities }\end{array}$ & $\begin{array}{c}\text { Additional } \\
\text { Designated Acres }\end{array}$ & $\begin{array}{c}\text { Average } \\
\text { Density }\end{array}$ & $\begin{array}{r}\text { Allowed Number of } \\
\text { Additional Units }\end{array}$ \\
\hline Low Density & 1,143 & 5 & 5,715 \\
\hline Medium Density & 312 & 10 & 3,123 \\
\hline High Density & 178 & 30 & 5,335 \\
\hline Total & & & 14,174 \\
\hline
\end{tabular}




\section{Commercial and Industrial Land}

In order to calculate the minimum commercial acreage needed in the city by 2030 , it was assumed that the ratio of the total population to the number of commercial acres would remain the same in the future. The number of residents $(12,707)$ per the number of commercial acres (38 acres) in 2010 resulted in a ratio of 334.3:1. This ratio was divided by the projected number of residents in 2030 (27,826 people) for a result of a projected 78 acres of commercial land needed by 2030. The Land Use Diagram exceeds this minimum need by accommodating for a total of 555 commercial acres.

This method was similarly used to project the minimum number of acres for manufacturing purposes for 2030 . The ratio of population $(12,707)$ to the number of acres in manufacturing use (17 acres) in 2010 resulted in 798:1. This ratio was divided by the projected population in 2030 (27,826 people) for a result of a projected 35 acres of manufacturing land needed by 2030 . The Land Use Diagram also exceeds this minimum need by accommodating for a total of 409 acres for industrial use.

\section{Land Use Standards}

This section describes each land use and the typically allowed building types for each use. In addition minimum and maximum allowed building densities for each residential use are indicated.

\section{Residential}

Allowable densities in residential areas are determined by the ratio of units to net acreage. Net acreage only includes buildable land and excludes streets and public rightof-ways. Allowed population densities for each area can be determined by multiplying the maximum allowed units per acre by the average people per household for the city. The average number of people per housing units was 4.7 in 2010. 


\section{Low Density Residential (LDR)}

Low density residential allows for the construction of detached single-family houses. A maximum of 8 units per acre is allowed in this land use. There is an average of 5 units per acre for low density residential land in the city. Low density residential land use is typically associated with R-1 zoning. Secondary units are allowed in this land use if certain conditions in the Zoning Code are met.

\section{Medium Density Residential (MDR)}

Allowable housing types in this land use are duplexes, triplexes, fourplexes, condominiums, townhouses, and mobile homes in mobile home parks. Allowable densities in this land use range between 8 and 20 units per acre. Medium density residential land use is typically associated with $\mathrm{R}-2$ and $\mathrm{R}-3$ zoning. There is an average of 10 units per acre for medium density residential land.

\section{High Density Residential (HDR)}

Housing types in this land use typically consist of apartments and those types listed for medium density residential use. Allowable densities in this land use range between 20 and 35 units per acre. High density residential land use is typically associated with R-4 zoning and usually allows for the construction of apartment complexes. High density residential areas should be located adjacent to major roadways.

\section{Mixed Use Overlay (MU)}

This land use designation is intended to allow for flexibility by allowing residential, commercial, and office uses on one parcel of land. This designation is particularly intended for areas in the urban core to allow for commercial and office uses on the first floor and residential use on the second floor. 


\section{Commercial}

Floor Area Ratio (FAR) standards are used to regulate the allowable intensity of buildings in commercial areas. This ratio is determined by the ratio of total square footage within a building to the net acreage of a parcel.

\section{Neighborhood Commercial (NC)}

The purpose of this use is to provide residential areas with basic commercial services. This designation allows for a variety of establishments including offices, supermarkets, restaurants, medical uses, banks, dry cleaning, and retail stores.

\section{Highway Commercial (HC)}

This use is meant to provide visitors traveling from Highway 99 with commercial services in addition to residents. Typical businesses allowed include large retail stores in addition to the establishments allowed in the neighborhood commercial use.

\section{Industrial}

\section{Light Industry (LI)}

Light industrial use areas allow for manufacturing uses which do not create a significant nuisance in terms of noise, odor, dust, smoke, and light. Office and research and development uses are also appropriate for areas designated for light industry.

\section{General Industry (I)}

This designation is intended for manufacturing uses which do create a nuisance in the form of noise, odor, dust, smoke, or light. Locating this use adjacent to residential uses is not appropriate. 


\section{Public Facilities}

Public Facilities uses include schools, City Hall, the Community Center, water sumps, the water treatment plant, the post office, and prisons. These uses are generally operated by a government agency.

\section{Goals, Policies, Programs}

\section{GOAL 2.1}

\section{Beautify the City.}

\section{POLICIES}

2.1.1. Implement street improvements such as landscaping, lighting, and sidewalks in the Downtown District and nearby freeway interchanges to attract visitors.

2.1.2 Ensure that new development meets city standards and codes.

2.1.3 All buildings which are a safety hazard shall be demolished or renovated.

\section{PROGRAMS}

2.1.1.1 The city should seek grant funding or consider creating a development impact fee to provide landscaping and tree planting improvements to streets.

2.1.2.1 The city Code Enforcement Officer should ensure that new and existing construction meets city development codes and the Zoning Ordinance.

2.1.3.1 The city shall enforce the State Housing Code which provides the proper procedure for demolishing and rehabilitating residential buildings deemed a public safety hazard. 
GOAL 2.2

Make the City more walkable with integrated neighborhoods.

\section{POLICIES}

2.2.1 Provide for a mixed-use district within the urban core of the city.

2.2.2 Create land designations which create and support village centers in specific areas of the city.

2.2.3 Create a trail system that links major nodes together such as parks, schools, the downtown district, and village centers.

\section{PROGRAMS}

2.2.1.1 Amend the zoning ordinance to create to a mixed use zone to allow for commercial development on the first floor and residential development on the second floor.

2.2.1.2 Amend the zoning map to zone parcels of land for mixed use which are in the mixed use designation of the land use diagram.

2.2.2.1 On land surrounded by Browning Rd., Sherwood Ave., Driver Rd., and Hanawalt Ave., designate a mixture of land uses to allow for commercial, manufacturing, park space, and low, medium, and high density residential uses.

2.2.3.1 Before approving new subdivisions, the city should consider requiring the developer to provide space for a trail system in addition to other provisions and impact fees. 


\section{GOAL 2.3}

\section{Foster economic growth.}

\section{POLICIES}

2.3.1 Focus on fostering economic growth in the "Downtown District", on land adjacent to highway interchanges, and on major corridors.

2.3.2 The city should look to attract large retail stores.

2.3.3 The city shall specifically designate areas for economic growth on the eastern portion of McFarland.

2.3.4 Attain a good jobs to housing balance to avoid becoming a bedroom community.

\section{PROGRAMS}

2.3.1.1 The city should acquire properties on the northern portion of Kern Ave. between 1st and 2nd street and demolish buildings and put out a Request for Proposals to commercial developers to redevelop the downtown district.

2.3.1.2 Designate land adjacent to the highway for retail and manufacturing purposes.

2.3.1.3 Locate new industrial sites adjacent to the railroad.

2.3.2.1 The city shall designate sufficiently large areas for commercial use in the land use diagram and in the zoning map to accommodate large retail stores.

2.3.3.1 Designate land for a mixed use village concept for commercial, park, mixed use, school, and low, medium, and high density residential use southeast of Sherwood Ave. and Browning Rd.

2.3.4.1 Designate ample land for commercial use and ensure that there is a higher proportion of land designated for commercial use compared to residential use than currently exists. 
GOAL 2.4

Provide citywide access to park space which provides adequate facilities.

\section{POLICIES}

2.4.1 The city and the McFarland Recreation and Park District should work to provide 5 acres of park space for every 1,000 residents.

2.4.2 The city shall ensure that developers provide adequate parks, park facilities, and/or funds for parks dependent upon the size and characteristics of their development.

\section{PROGRAMS}

2.4.1.1 Locate additional parks on the southeast, northeast, northwest, and southwest portions of the City.

2.4.2.1 The city shall create conditions of approval with developers which specifically describe the facilities which the park will include and then make sure that these facilities are constructed.

\section{GOAL 2.5}

Accommodate for the development of a diversity of housing densities.

\section{POLICIES}

2.5.1 The city shall amend its land use map and zoning map to provide land for low, medium and high density residential areas and to avoid a predominance of low density residential areas.

\section{PROGRAMS}

2.5.1.2 Land is designated for high, medium, and low density residential use throughout the Planning Area in the Land Use Diagram. 
GOAL 2.6

\section{Utilize wise land use practices.}

\section{POLICIES}

2.6.1 Incompatible uses shall be separated or buffered from one another.

2.6.2 The city should avoid locating new urban growth in areas designated by the Federal Emergency Management Agency (FEMA) to be hazardous in terms of flooding.

Any development approved in a flood plain shall be required to meet certain requirements to mitigate risk of damage to buildings from a flood.

2.6.3 Higher density land uses should be located adjacent to major roadways to minimize the number of roadways which need to be improved to meet increased Level of Service demands.

\section{PROGRAMS}

2.6.1.1 Commercial and industrial development shall be compatible with surrounding uses and/or incompatible characteristics shall be mitigated.

2.6.2.1 Whenever city staff receives a development application, staff shall determine if the proposed development is located in a floodplain designated by the Federal Emergency Management Act. If the development is in a floodplain, then city staff shall require that the development meet certain conditions approved by FEMA to mitigate flood damage before approving such development.

2.6.3.1 Higher density land uses are generally located along the major roadways of Sherwood Ave., Perkins Ave., Elmo Highway, and Garzoli Blvd. 
GOAL 2.7

\section{Manage growth to reduce sprawl and preserve agricultural land.}

\section{POLICIES}

2.7.1 The city shall provide for a higher proportion of compact development than currently exists.

2.7.2 The city shall not allow leapfrog development.

\section{PROGRAMS}

2.7.1.1 The Land Use Diagram provides for larger proportion of medium and high density residential land to low density residential land than currently exists.

2.7.2.1 The city shall only allow new development to occur on infill sites or on land adjacent to existing urban development and only when services and infrastructure are available or will be provided.

\section{Additional Actions}

In order to implement these goals, policies, programs and the Land Use Diagram, the city shall amend the Zoning Ordinance and update the Zoning Map to be consistent with this document within 2 years of approval of this document. The zones of Highway Commercial, Mixed Use, and Urban Reserve will need to be added to the Zoning Ordinance to help ensure consistency with this document. Developed parcels with existing uses which are not in conformance with the updated Zoning Map will be allowed to continue their respective existing uses. However, owners of these parcels will not be allowed to add to such non-conforming uses beyond their extent once the Zoning Map is updated. 
The city shall review this Land Use Element every five years to ensure that it is continually implemented. Additionally, the city should create and continually update a map of vacant parcels within city limits along with their zoning designation to provide to interested developers. Finally, the city should also work to influence the planning of new residential tract developments such that parcels have a passive solar orientation.

Finally, the city should improve the level of participation by community stakeholders in future outreach efforts. One recommendation is that city staff goes out into the community with a Spanish/English bilingual person and directly ask residents and property owners for input relevant to the task at hand. It cannot be claimed that the level of participation for community outreach for this Land Use Element is representative of the community since 18 people out of a community with 12,700 people is not a representative sample. Future outreach efforts by city staff should include an adamant effort to get input from a much more representative sample of the community. If input from community members is used to make decisions for the city's future, it is crucial that the input received represents a very significant proportion of the community. 


\section{Appendices}

\section{Community Feedback}

\section{GPAC Meeting 1}

- A central theme was the importance of beautifying the city to make it more desirable for businesses to develop here and for people to visit and move here. A few of the GPAC members expressed the need for lighting to increase the perception of safety and to attract visitors from Highway 99. Demolishing and rehabilitating derelict buildings and hiring a code enforcer to ensure that buildings meet city standards were other proposed strategies for beautifying the city.

- Improve the Downtown District (Kern Ave.) to create a nice downtown commercial corridor like other cities (i.e. Delano).

- Improve the sewer access which connects East McFarland to the wastewater treatment plant to allow for new development in East McFarland.

- Create new future parks and improve existing park facilities. Many of the existing parks lack restrooms (or clean restrooms), seating area, and shade. The city should force developers of tract developments to provide adequate park facilities or adequate in-lieu fees to provide facilities.

- Focus on building a tax base for the city by increasing the proportion of businesses to residences. Businesses provide more tax money to the city and require fewer services than residences. In addition to attracting new commercial development, the city can have dialogue with owners of businesses in the city to determine feasible things the city can do for them (i.e. street/sidewalk improvements). 
- Utilize the railroad by locating new development near it (particularly industrial and commercial).

\section{Cinco de Mayo Fair}

- The city needs some large retail stores to provide jobs and so that residents do not have to drive to Delano to shop for groceries and other items.

- The city could use more housing options for senior citizens.

- The city should initiate a volunteer program to provide opportunities for people who want to help out in the community.

- People like that the city is small.

- The city could use more options for things to do and places to hang out.

- The old abandoned buildings should be torn down to improve the appearance of the Downtown District.

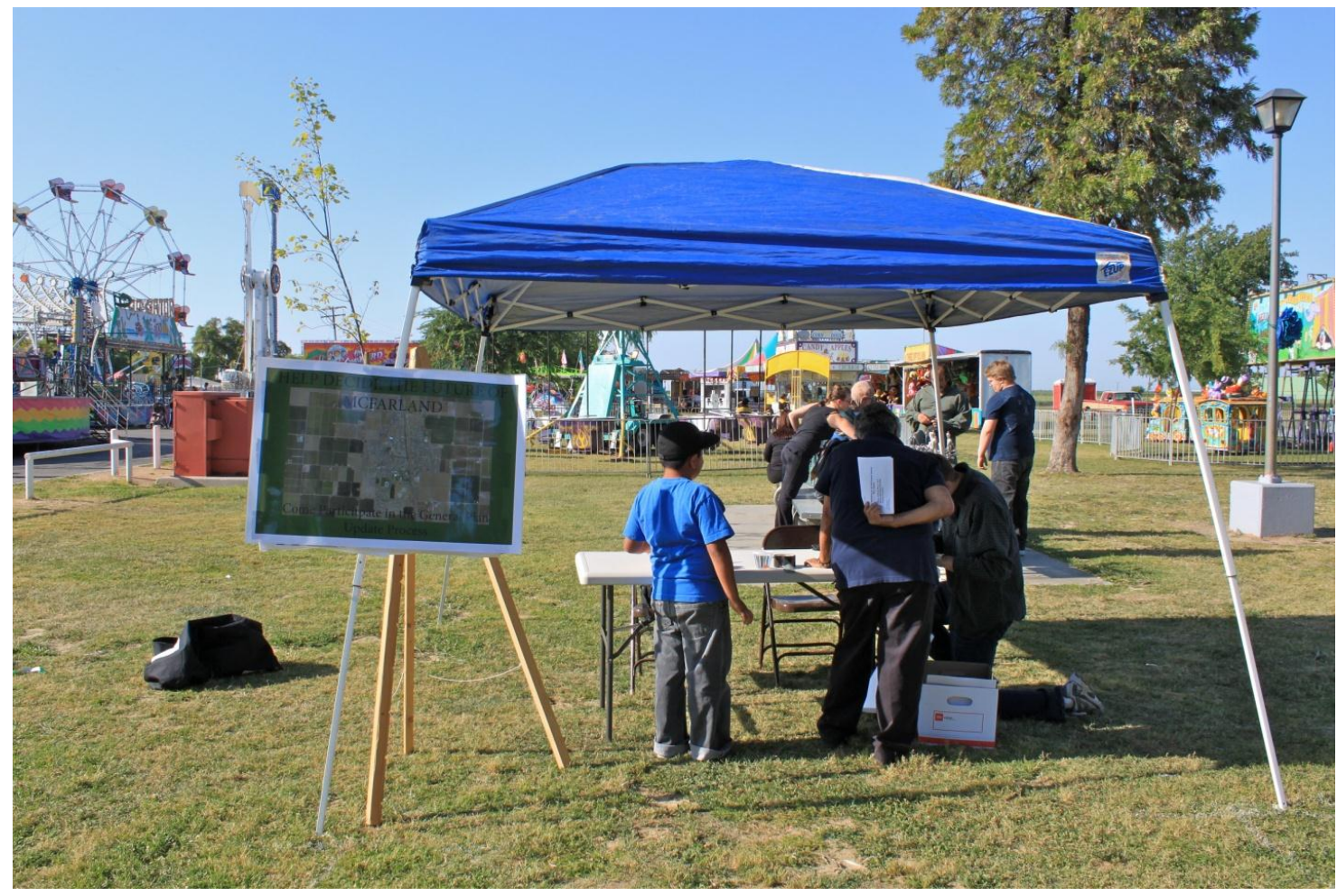

McFarland residents providing input at the booth at the Cinco de Mayo Festival. 


\section{Public Workshop 1}

A central theme of feedback from this workshop was creating a walkable community. Some of the participants commented on the desirability of mixed use neighborhoods and a trail system connecting schools, parks, businesses, and residences. In addition, providing a plaza in the Downtown District was recommended to improve walkability and to accommodate the interest of Latinos in using public spaces.

Workshop participants responded that things they like about McFarland are: small town feel, the humble people, schools, parks, agricultural heritage, and the freeway access.

Participants provided the following comments regarding desired short term changes for the city: Put up street lights, economic development, downtown beautification, a trail system, multi-zone planning, plant trees on certain streets, the construction of a senior center and of senior citizen's apartments, increase public services and economic development on the East side, road and sidewalk improvements, and clean up the litter.

In response to desired long term changes, comments included: more schools, more parks, more activities for kids, commercial and industrial development, larger parks, thriving downtown businesses, and a long-term city manager.

After discussing these three questions as a group, we moved on to a mapping activity to identify desirable locations of land uses in the city. Through this activity, some participants indicated that they wanted to allow mixed use development in the Downtown District. Another comment was changing the area between Sherwood Ave, Kern Ave., $2^{\text {nd }}$ St., and Highway 99 to commercial. Some participants indicated that they wanted to 
focus new facilities and development on the East side since it is currently lacking in businesses and facilities.

In addition, city staff distributed and collected surveys regarding various land use issues (see Appendix A). 
Appendix A: Community Land use Survey

\section{City of McFARLAND}

401 W. Kern Ave, McFarland, CA 92350 mcfarlandcity.org 661-792-3091 office

\section{GENERAL PLAN UPDATE for 2011 - 2031 \\ Community Land Use Survey}

\section{WE NEED YOUR HELP TO GUIDE THE FUTUER OF MCFARLAND.}

Please take a few minutes and give us your comments and ideas by filling out the following this survey:

What are 3 things that you like about McFarland?

1.

2.

3.

What are 3 things you want to change about McFarland - Short Term?

1.

2.

3.

What are 3 things you want to change about McFarland - Long Term?

1.

2.

3.

Prioritize the importance of each of the following to you by numbering 1 through 5 (where 1 is the highest importance and 5 is the least).

Additional School Facilities; $\square$ More Park Space; $\square$ More Affordable Housing;

A More Attractive Downtown; $\square$ Other:

Should the City encourage higher density (smaller lot) development to preserve more agricultural land and open space? 
Strongly Agree; $\square$ Agree; $\square$ Indifferent; $\square$ Disagree; $\square$ Strongly Disagree

Do you like the idea of having village centers in McFarland where businesses, housing and parks are interspersed in the same neighborhood? $\square$ Strongly Agree; $\square$ Agree; Indifferent; $\square$ Disagree; $\square$ Strongly Disagree

What types of uses are best suited for land adjacent to Highway 99? (select all that apply)

$\square$ Freeway oriented fast food outlets; $\square$ Light industry; $\square$ Distribution center for big retailers;

Retail stores; $\square$ Office; $\square$ High density housing; $\square$ Mixed Use;

Others:

What strategies do you think we can pursue to capitalize on the City's proximity to Highway 99 and to the railroad?

What can be done to improve the physical appearance of the Downtown McFarland?

What types of supporting community facilities are needed?

$\square$ New park space; $\square$ Improvement of existing parks; $\square$ Theater, cinema;

Neighborhood commercial; $\square$ Playground for kids; $\square$ Adult education center; Daycare facilities;

Others

Do you have any general comments relating to these issues (or other issues) which you feel are important for a vision for the future of McFarland?

\section{THANK YOU FOR YOUR PARTICIPATION! Bring this to the public meeting or mail or drop off at city hall or email to Pam Hill, Planner at phill@mcfarlandcity.org}




\section{GPAC Meeting 2}

The purpose of this meeting was to generate strategies to implement the goals mentioned in the previous public workshop and the first GPAC meeting and to identify desirable land uses for particular areas outside of the city limits. Some GPAC members recommended focusing street improvements (i.e. lights, trees, painting street lines) at freeway exits, Frontage Rd., parks, and at the Downtown District. Another strategy supported by most GPAC members was having city planning staff provide advice for conditions of approval for new development to city council and then ensuring that conditions of approval are carried through.

\section{GPAC Meeting 3}

In this meeting the GPAC members reviewed two alternative land use maps (see Figures $A$ and $B$ ) to provide guidance on the extent to which they want the city to grow. In addition, GPAC members provided feedback regarding how they liked the distribution of land uses on these alternatives and what changes they wanted to see. There was a general agreement to make a lot more land available for development in the future than would be needed to accommodate the projected population growth. In addition, the "urban reserve" designation was liked by GPAC members for land not adjacent to city limits as a way of making land available for development in the future but not immediately so as to accommodate "leap frog" development. "Leap frog" development is where new urban development occurs which is not adjacent to existing urban development and is separated by agricultural or vacant land. One member stressed that Garzoli Blvd. would be a major throughway in the future and wanted to see some more commercial land along this road. Another GPAC member liked that manufacturing land was located adjacent to Highway 99 to avoid locating it next to neighborhoods and reduce impacts on local roads. 
Appendix B: Alternative Land Use Map 1

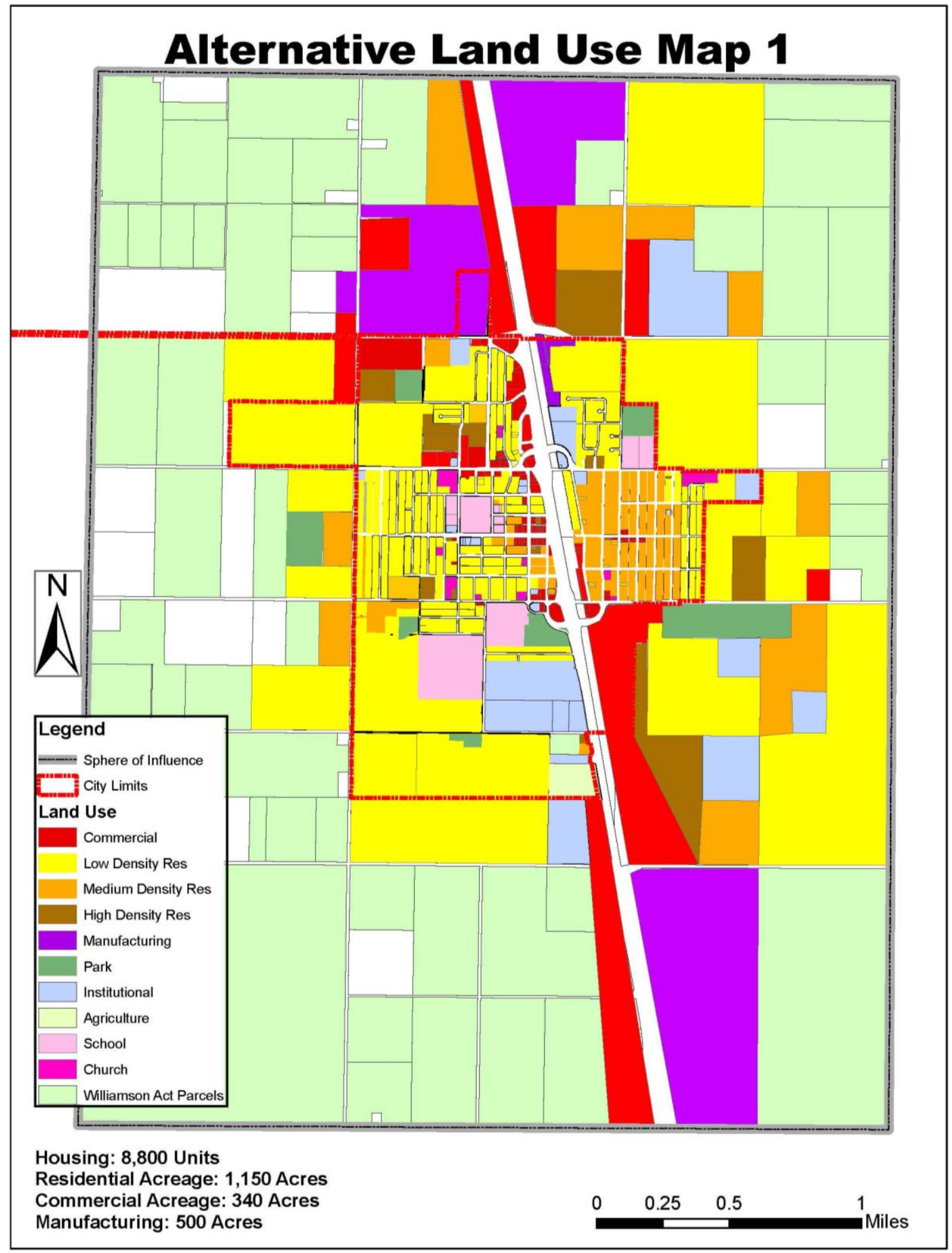


Appendix C: Alternative Land Use Map 2

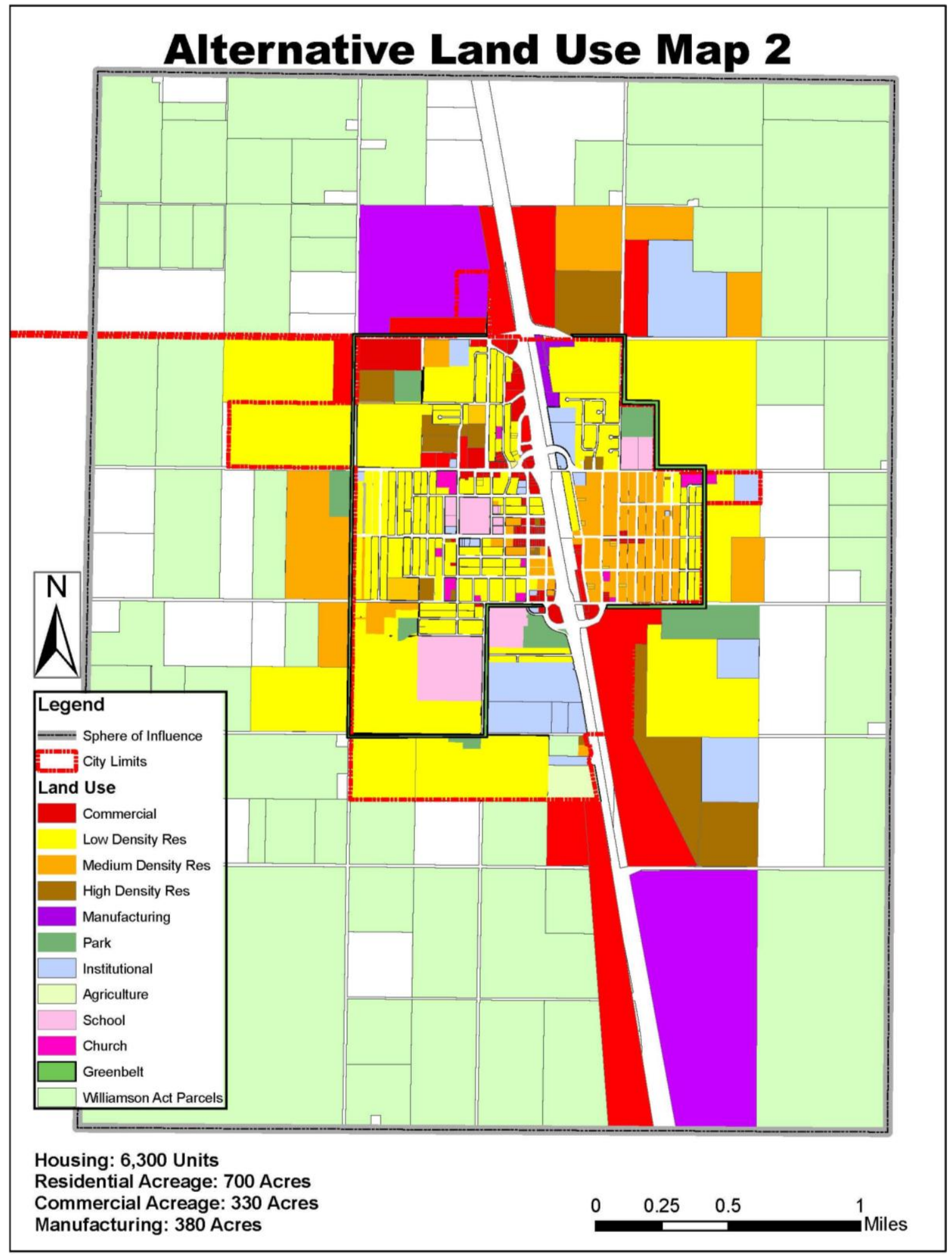




\section{Public Workshop 2}

- Make $2^{\text {nd }}$ Street the new "Main Street" for downtown McFarland. Plant Palm trees and install lighting fixtures along this street to help signify its importance as the "Main Street" for the city.

- Importance of identifying locations of future on and off ramps for Highway 99 in how land uses are distributed in the city.

- Need improvements to the sewer system to connect the East side to the waste water treatment plant to allow for significant growth on the East side.

\section{Goals, Policies, Programs}

The following goals, policies, and programs (in Appendix D) are included in this Land Use Element and were largely created using the feedback generated during community outreach efforts. Some of these goals, policies, and programs were also created using planning methods generally identified as good practice. 
Appendix D: Goals, Policies, and Programs Table

\begin{tabular}{|c|c|c|}
\hline Goals & Policies & Programs \\
\hline \multirow{3}{*}{$\begin{array}{l}\text { Beautify the } \\
\text { City. }\end{array}$} & $\begin{array}{l}\text { Implement street } \\
\text { improvements such as } \\
\text { landscaping, lighting, and } \\
\text { sidewalks in the } \\
\text { Downtown District and } \\
\text { nearby freeway } \\
\text { interchanges to attract } \\
\text { visitors. }\end{array}$ & $\begin{array}{l}\text { The City should seek grant funding or } \\
\text { consider creating a development impact } \\
\text { fee to provide landscaping and tree } \\
\text { planting improvements to streets. }\end{array}$ \\
\hline & $\begin{array}{l}\text { Ensure that new } \\
\text { development meets City } \\
\text { standards and codes. }\end{array}$ & $\begin{array}{l}\text { The City Code Enforcement Officer } \\
\text { should ensure that new and existing } \\
\text { construction meets City development } \\
\text { codes and the Zoning Ordinance. }\end{array}$ \\
\hline & $\begin{array}{l}\text { All buildings which are a } \\
\text { safety hazard shall be } \\
\text { demolished or renovated. }\end{array}$ & $\begin{array}{l}\text { The City shall enforce the State Housing } \\
\text { Code which provides the proper } \\
\text { procedure for demolishing and } \\
\text { rehabilitating residential buildings deemed } \\
\text { a public safety hazard. }\end{array}$ \\
\hline \multirow{5}{*}{$\begin{array}{l}\text { Make the City } \\
\text { more walkable } \\
\text { with integrated } \\
\text { neighborhoods. }\end{array}$} & \multirow[t]{2}{*}{$\begin{array}{l}\text { Provide for a mixed-use } \\
\text { district within the urban } \\
\text { core of the City. }\end{array}$} & $\begin{array}{l}\text { Amend the zoning ordinance to create to } \\
\text { a mixed use zone to allow for commercial } \\
\text { development on the first floor and } \\
\text { residential development on the second } \\
\text { floor. }\end{array}$ \\
\hline & & $\begin{array}{l}\text { Amend the zoning map to zone parcels of } \\
\text { land for mixed use which are in the mixed } \\
\text { use designation of the land use diagram. }\end{array}$ \\
\hline & \multirow{2}{*}{$\begin{array}{l}\text { Create land designations } \\
\text { which create and support } \\
\text { village centers in specific } \\
\text { areas of the City. }\end{array}$} & $\begin{array}{l}\text { On land surrounded by Browning Rd., } \\
\text { Sherwood Ave., Driver Rd., and Hanawalt } \\
\text { Ave., designate a mixture of land uses to } \\
\text { allow for commercial, manufacturing, park } \\
\text { space, and low, medium, and high density } \\
\text { residential uses. }\end{array}$ \\
\hline & & $\begin{array}{l}\text { With permission from the Local Agency } \\
\text { Formation Commission, annex land } \\
\text { surrounded by Browning Rd., Sherwood } \\
\text { Ave., Driver Rd., and Hanawalt Ave. into } \\
\text { City limits. }\end{array}$ \\
\hline & $\begin{array}{l}\text { Create a trail system that } \\
\text { links major nodes } \\
\text { together such as parks, } \\
\text { schools, the downtown } \\
\text { district, and village }\end{array}$ & $\begin{array}{l}\text { Focus this new trail system in new growth } \\
\text { areas such as the southeastern portion of } \\
\text { the City South of Sherwood Ave. and the } \\
\text { western portion of the City along Garzoli } \\
\text { Ave. }\end{array}$ \\
\hline
\end{tabular}




\begin{tabular}{|c|c|c|}
\hline & centers. & $\begin{array}{l}\text { Before approving new subdivisions, the } \\
\text { City should consider requiring the } \\
\text { developer to provide space for a trail } \\
\text { system in addition to other provisions and } \\
\text { impact fees. }\end{array}$ \\
\hline \multirow{6}{*}{$\begin{array}{l}\text { Foster } \\
\text { economic } \\
\text { growth. }\end{array}$} & \multirow{3}{*}{$\begin{array}{l}\text { Focus on fostering } \\
\text { economic growth in the } \\
\text { "Downtown District" and } \\
\text { on land adjacent to } \\
\text { highway interchanges to } \\
\text { attract visitors. }\end{array}$} & $\begin{array}{l}\text { The City should acquire properties on the } \\
\text { northern portion of Kern Ave. between 1st } \\
\text { and } 2 \text { nd street and demolish buildings } \\
\text { and put out a Request for Proposals to } \\
\text { commercial developers to redevelop the } \\
\text { downtown district. }\end{array}$ \\
\hline & & $\begin{array}{l}\text { Designate land adjacent to the highway } \\
\text { for retail and manufacturing purposes. }\end{array}$ \\
\hline & & $\begin{array}{l}\text { Locate new industrial sites adjacent to the } \\
\text { railroad. }\end{array}$ \\
\hline & $\begin{array}{l}\text { The City should look to } \\
\text { attract large retail stores. }\end{array}$ & $\begin{array}{l}\text { The City shall designate sufficiently large } \\
\text { areas for commercial use in the land use } \\
\text { diagram and in the zoning map to } \\
\text { accommodate large retail stores. }\end{array}$ \\
\hline & $\begin{array}{l}\text { The City shall specifically } \\
\text { designate areas for } \\
\text { economic growth on the } \\
\text { eastern portion of } \\
\text { McFarland. }\end{array}$ & $\begin{array}{l}\text { Designate land for a mixed use village } \\
\text { concept for commercial, park, mixed use, } \\
\text { school, and low, medium, and high } \\
\text { density residential use southeast of } \\
\text { Sherwood Ave. and Browning Rd. }\end{array}$ \\
\hline & $\begin{array}{l}\text { Attain a good jobs to } \\
\text { housing balance to avoid } \\
\text { becoming a bedroom } \\
\text { community. }\end{array}$ & $\begin{array}{l}\text { Designate ample land for commercial use } \\
\text { and ensure that there is a higher } \\
\text { proportion of land designated for } \\
\text { commercial use compared to residential } \\
\text { use than currently exists. }\end{array}$ \\
\hline \multirow{2}{*}{$\begin{array}{l}\text { Citywide } \\
\text { access to park } \\
\text { space which } \\
\text { provides } \\
\text { adequate } \\
\text { facilities. }\end{array}$} & $\begin{array}{l}\text { The City and the } \\
\text { McFarland Recreation } \\
\text { and Park District should } \\
\text { work to provide } 5 \text { acres of } \\
\text { park space for every } \\
1,000 \text { residents. }\end{array}$ & $\begin{array}{l}\text { Locate additional parks on the southeast, } \\
\text { northeast, northwest, and southwest } \\
\text { portions of the City. }\end{array}$ \\
\hline & $\begin{array}{l}\text { The City shall ensure that } \\
\text { developers provide } \\
\text { adequate parks, park } \\
\text { facilities, and/or funds for } \\
\text { parks dependent upon the } \\
\text { size and characteristics of } \\
\text { their development. }\end{array}$ & $\begin{array}{l}\text { The City shall create conditions of } \\
\text { approval with developers which } \\
\text { specifically describe the facilities which } \\
\text { the park will include and then make sure } \\
\text { that these facilities are constructed. }\end{array}$ \\
\hline $\begin{array}{l}\text { Diversified } \\
\text { housing }\end{array}$ & $\begin{array}{l}\text { The City shall amend its } \\
\text { land use map and zoning } \\
\text { map to have sufficient } \\
\text { low, medium and high }\end{array}$ & $\begin{array}{l}\text { Land is designated for high, medium, and } \\
\text { low density residential use throughout the } \\
\text { Planning Area in the Land Use Diagram. }\end{array}$ \\
\hline
\end{tabular}




\begin{tabular}{|c|c|c|}
\hline & $\begin{array}{l}\text { density residential areas } \\
\text { to meet projected } \\
\text { demand. }\end{array}$ & \\
\hline \multirow{3}{*}{$\begin{array}{l}\text { Utilize wise } \\
\text { land use } \\
\text { practices. }\end{array}$} & $\begin{array}{l}\text { Incompatible uses shall } \\
\text { be separated or } \\
\text { buffered from each } \\
\text { other. }\end{array}$ & $\begin{array}{l}\text { Commercial and industrial } \\
\text { development shall be compatible with } \\
\text { surrounding uses and/or incompatible } \\
\text { characteristics shall be mitigated. }\end{array}$ \\
\hline & $\begin{array}{l}\text { The City should avoid } \\
\text { locating new urban } \\
\text { growth in areas } \\
\text { designated by the Federal } \\
\text { Emergency Management } \\
\text { Agency (FEMA) to be } \\
\text { hazardous in terms of } \\
\text { flooding. Any } \\
\text { development approved in } \\
\text { a flood plain shall be } \\
\text { required to meet certain } \\
\text { requirements to mitigate } \\
\text { risk of damage to } \\
\text { buildings from a flood. }\end{array}$ & $\begin{array}{l}\text { Whenever City Staff receive a } \\
\text { development application, Staff shall } \\
\text { determine if the proposed development is } \\
\text { located in a floodplain designated by the } \\
\text { Federal Emergency Management Act. If } \\
\text { the development is in a floodplain, then } \\
\text { City Staff shall require that the } \\
\text { development meet certain conditions } \\
\text { approved by FEMA to mitigate flood } \\
\text { damage before approving such } \\
\text { development. }\end{array}$ \\
\hline & $\begin{array}{l}\text { Higher density land uses } \\
\text { should be located } \\
\text { adjacent to major } \\
\text { roadways to minimize the } \\
\text { number of roadways } \\
\text { which need to be } \\
\text { improved to meet } \\
\text { increased Level of } \\
\text { Service demands. }\end{array}$ & $\begin{array}{l}\text { Higher density land uses are generally } \\
\text { located along the major roadways of } \\
\text { Sherwood Ave., Perkins Ave., Elmo } \\
\text { Highway, and Garzoli Blvd. }\end{array}$ \\
\hline \multirow{2}{*}{$\begin{array}{l}\text { Manage growth } \\
\text { to reduce } \\
\text { sprawl and } \\
\text { preserve } \\
\text { agricultural } \\
\text { land. }\end{array}$} & $\begin{array}{l}\text { The City shall provide for } \\
\text { a higher proportion of } \\
\text { compact development } \\
\text { than currently exists. }\end{array}$ & $\begin{array}{l}\text { The Land Use Diagram provides for larger } \\
\text { proportion of medium and high density } \\
\text { residential land to low density residential } \\
\text { land than currently exists. }\end{array}$ \\
\hline & $\begin{array}{l}\text { The City shall not allow } \\
\text { leapfrog development. }\end{array}$ & $\begin{array}{l}\text { The City shall only allow new } \\
\text { development to occur on infill sites or on } \\
\text { land adjacent to existing urban } \\
\text { development and only when services and } \\
\text { infrastructure are available or will be } \\
\text { provided. }\end{array}$ \\
\hline
\end{tabular}




\section{Case Studies}

\section{Farmersville, CA}

The City of Farmersville, CA land use element is exemplary because it won an American Planning Association award for a rural General Plan. Additionally, the population size and ethnicity composition of Farmersville is similar to McFarland and Farmersville is geographically close to McFarland. This document is a good example of a recent work that incorporates a direction towards "smart growth" principles that many governments are heading towards and that is applied to a small rural area. A few of the "smart growth" measures in this element are mixed use, infill development, pedestrianoriented commercial development and a central business core (Collins \& Schoettler, 2002).

\section{Taft, CA}

Another exemplary case study is the City of Taft, CA 2004 land use element. Taft is geographically close to McFarland and this land use element displays clarity of organization and content. This document clearly identifies the increase in number of acres of residential, commercial, industrial, parks, and schools needed to accommodate projected population growth and how these numbers were calculated. Additionally, very comprehensive goals and policies are broken down into particular areas of focus (i.e. growth management, economic development, guiding how land for parks and schools is dedicated and childcare facilities) (Collins \& Schoettler, 2004).

\section{Delano, CA}

The City of Delano, CA 2005 land use element does a good job of addressing intergovernmental coordination. It describes policies of the Kern County Urban Boundaries Policies and the Comprehensive Policy Plan of the County of Tulare which 
pertain to lands surrounding the City. It also includes collaborative efforts to ensure that Delano land use policies do not conflict with the Kern County or Tulare County governments. Delano is located about 5 miles North of McFarland and deals with many of the same issues as McFarland (i.e. surrounded by farmland, struggling with economic blight). Also, the Delano future land use map utilizes the smart growth principle of planning for a mixture of uses throughout the City with dispersed dense core areas.

\section{Kerman, CA}

Finally, the City of Kerman land use element is noteworthy for requiring the Planning Commission and the City Council make a finding that new development will occur within 1/8 mile of existing approved development. In support of this, a policy in the document states that new development cannot extend beyond the 2017 Growth Boundary Line unless the area contains $80 \%$ infill or the City Council decides that there is a need for affordable housing, open space, or due to obstacles to growth.

Preservation of farmland has been identified in the Kern COG Regional Blueprint Plan as a very important goal and these Kerman land use policies can help to influence the preservation of farmland in McFarland. 


\section{Bibliography}

2000 U.S. Census.

2010 U.S. Census.

Berke et. al. 2006. Urban Land Use Planning. University of Illionis Press: Urbana ad Chicago, II.

Collins \& Shoettler Planning Consultants..Farmersville, CA General Plan. 2002 land use element.

Collins \& Shoettler Planning Consultants. Taft, CA Draft General Plan. 2004 land use element.

Delano, CA General Plan. 2005 land use element.

Hopkins, Lewis. (2001). Urban Development: The Logic of Making Plans.

Longitudinal Employer-Household Dynamics. http://lehd.did.census.gov/led/.

Moore lacofano Goltsman, Inc. 2008. Kern Regional Blueprint Program: Phase Two Summary Report - Community Outreach.

Myers, Dowell. 2001. "Demographic futures as a guide to planning: California's Latinos and the compact city." Journal of the American Planning Association. 67: 4, Pp. 388.

Office of Planning and Research. (2003). General Plan Guidelines.

Sanoff, Henry. (2000). Community Participation Methods in Design and Planning.

Stephens, Josh. 2008. "Out of the Enclave: Latinos Adapt, and Adapt to, The American City." http://www.planetizen.com/node/35091. 